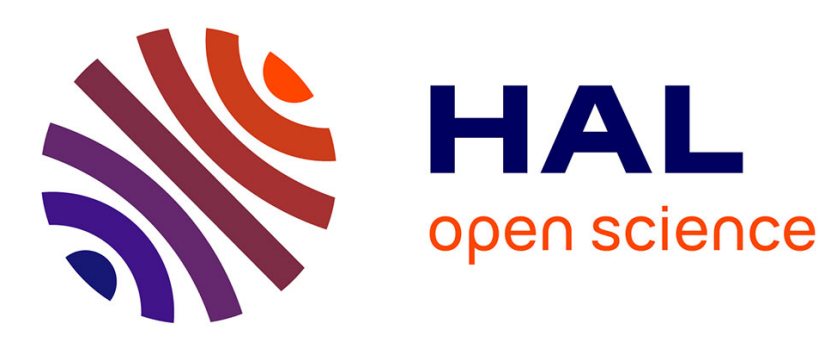

\title{
Experimental study on a scaled test model of soil reinforced by stone columns
}

\author{
Abdelkhalek Bouziane, Frédéric Jamin, Abdennabi El Mandour, Mohamed El \\ Omari, Mounir Bouassida, Moulay Saïd El Youssoufi
}

\section{- To cite this version:}

Abdelkhalek Bouziane, Frédéric Jamin, Abdennabi El Mandour, Mohamed El Omari, Mounir Bouassida, et al.. Experimental study on a scaled test model of soil reinforced by stone columns. European Journal of Environmental and Civil Engineering, 2020, pp.1-20. 10.1080/19648189.2020.1716852 . hal-03346624

\section{HAL Id: hal-03346624 \\ https://hal.science/hal-03346624}

Submitted on 16 Sep 2021

HAL is a multi-disciplinary open access archive for the deposit and dissemination of scientific research documents, whether they are published or not. The documents may come from teaching and research institutions in France or abroad, or from public or private research centers.
L'archive ouverte pluridisciplinaire HAL, est destinée au dépôt et à la diffusion de documents scientifiques de niveau recherche, publiés ou non, émanant des établissements d'enseignement et de recherche français ou étrangers, des laboratoires publics ou privés. 
1 Experimental Study on a Scaled Test Model of Soil Reinforced by

2 Stone Columns

3 Abdelkhalek BOUZIANE ${ }^{1,2}$, Frédéric JAMIN³ , Abdennabi EL

4 MANDOUR $^{2}$, Mohamed EL OMARI ${ }^{1}$, Mounir BOUASSIDA ${ }^{4}$ and Moulay

5 Saïd EL YOUSSOUFI ${ }^{3}$

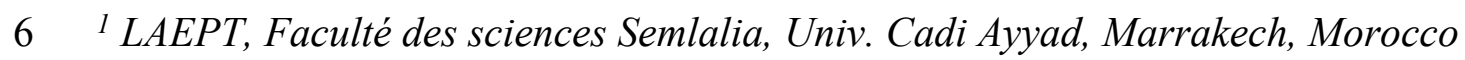

$7 \quad{ }^{2}$ Laboratoire GEOHYD, Faculté des sciences Semlalia, Univ. Cadi Ayyad, Marrakech,

8 Morocco

$9 \quad{ }^{3}$ LMGC, Univ. Montpellier, CNRS, Montpellier, France

$10{ }^{4}$ Université de Tunis El Manar LRIG, École Nationale d'Ingénieurs de Tunis, Tunis,

11 Tunisia

$12 *$ Corresponding author: frederic.jamin@umontpellier.fr 


\section{Experimental Study on a Scaled Test Model of Soil Reinforced by \\ 2 Stone Columns}

This paper presents results of experimental tests on soil specimens reinforced by stone columns. The experimental investigations have been conducted by setting up a laboratory scale model. The main objective is to evaluate the effects of various reinforcing materials and stone columns configurations on the axial deformation during a vertical loading test of cylindrical samples of unreinforced and reinforced soil. The findings have been compared to existing experimental results proposed in literature. The specimens of soil consisted in an analogic material of poly-dispersed glass beads with a grain size smaller than $50 \mu \mathrm{m}$. Two reinforcing materials have been considered as ballasts: crushed sand and coarser granularity glass beads $(0.7-1.0 \mathrm{~mm})$. The results show that the material type and spacing between columns in a triangular or square configuration can greatly affect the reinforcement efficiency. The proposed results are applicable to predict the improvement of granular soils of medium density when subjected to the vibrocompaction technique.

Keywords: Reinforcement; compressible soil; stone columns; test model; bearing capacity; granular material.

\section{Introduction}

Since the seventies stone columns reinforcement has become an increasingly popular technique, especially for infrastructure projects. According to Eurocode 7, stone

columns are flexible inclusions consisting of purely rubbing, rolled or crushed granular materials, which generally have much better mechanical properties than those of the insitu soil. Since the use of this technique to solve many problems of construction over compressible soils has become widespread, the dimensioning of the reinforcement systems by stone columns is still poorly understood (Soyez, 1985 and Priebe, 1995).

The calculation procedures are not suitable for the practical cases faced by engineers. In general, the stone columns are frequently employed to improve the mechanical properties of in-situ soil enabling an increase in bearing capacity, settlement reduction, 
1 acceleration of consolidation and contributing to the overall stability of structures in

2 order to minimize the risk of liquefaction in seismic zones.

In this paper, a bibliographic review of column soil reinforcement is presented.

4 Then, an experimental study is developed with the objective of studying the behaviour

5 of soil reinforced by end-bearing stone columns under oedometer conditions. The

6 experimental equipment and the materials constituting the reinforced soil are itemized.

7 The tests which have been performed and the obtained results are presented and

8 followed by interpretations to explain the observed behaviour of the composite soil-

9 column system. Recommendations related to the applicability of proposed are also

10 outlined.

\section{$11 \quad 1.1 \quad$ In situ tests}

12 Several in-situ testing procedures can be used to identify the type of materials, the

13 particles size curves of aggregates, the arrangement of the columns (isolated, in a square

14 or triangular pattern) or even the practical installation of the stone columns (dry or wet,

15 driving, vibrations) influence the mechanical behaviour of reinforced soil. For example,

16 the stone column technique has shown its effectiveness in reducing the deposits in

17 several research papers (Vautrain, 1980 and Corneille, 2007).

18 Vautrain (1980) showed that the cohesion and the internal friction angle of soil

19 under an embankment were improved due to reinforcement by stone columns. This

20 conclusion was achieved by noticing the difficulty of the vane blades penetration during

21 in-situ tests. The interpretation of this observed phenomenon leads to the establishment

22 of a calculation method to predict the behaviour of the stone columns. Corneille (2007)

23 performed loading tests to determine areas that experience a lateral expansion failure

24 detected by inclinometers installed on both sides of the column. The effect of the

25 number of installed columns was presented and the settlement of soil reinforced by 
1 three columns was compared to that of unreinforced soil. The obtained results showed

2 that column failure manifests at a depth equal to three times the diameter of the column.

3 In addition, it was found that the compaction of the reinforced soil is $35 \%$ less

4 important than that of natural soil. Furthermore, the draining effect of the columns was

5 demonstrated by the installation of pore pressure cells that indicated an immediate

6 increase in excess pore pressures after loading. Similar results was reported by McCabe

7 et al. (2009) from about twenty sites of soil reinforced by stone columns.

This draining effect of the stone columns reduces the risk of liquefaction in

9 seismic zones (Adalier et al., 2003, Adalier \& Elgamal, 2004 and BenSalem et al., 10 2017). The installation of stone columns in soft soils by lateral expansion induces the 11 improvement of initial soil properties (Guetif et al., 2007, Zahmatkesh \& Choobbasti, 12 2010). Indeed, these researchers showed that the distribution of the horizontal stress changes after the installation of the column, which explains the variation of its diameter

14 throughout its depth. The results also showed that the generated stress around the

15 column decreases away from the axis of the column. Several papers highlighted the

16 lateral expansion after the installation of stone columns, which generally occurs from

17 the column towards the surrounding soil (Castro \& Sagaseta, 2011, Rangeard et al., 182016 and Ellouze et al., 2017). This expansion depends on the consistency of the soil

19 layer crossed by the column. Frikha et al. (2013) used results of pressure meter tests to

20 illustrate how initial soil improvement occurs after installation of columns.

\section{$21 \quad 1.2 \quad$ Experiments on scaled test models}

22 Triaxial tests have been widely used to study effects of soil reinforcement (Sivakumar et al., 2004, Najjar et al., 2010 and Frikha et al., 2014). Other researchers performed

24 laboratory tests on reduced-scale models (Bouassida, 1996, Isaac \& Girish, 2009, Hasan et al., 2011, Shahu \& Reddy, 2011, Pivarč, 2011, Rangeard et al., 2016 and Fattah et 
1 al., 2017). These studies analysed the effect of ballast gradation, columns diameter $\left(D_{c}\right)$,

2 anchorage depth $\left(\mathrm{L}_{\mathrm{c}}\right)$ and column installation (with or without backflow, with or

3 without compaction) on the reinforcement effectiveness.

4

Andreou et al. (2008) investigated the grain size effect of column material. The results obtained during triaxial loadings tests showed that, under the same confinement conditions, a soil reinforced by a sand column with an average diameter of $0.38 \mathrm{~mm}$ improves the considered soils, with focus on the bearing capacity, compared to a coarser gravel-type material with an average diameter of $1.25 \mathrm{~mm}$. In addition, the study showed that a low value of confinement stress (close to $50 \mathrm{kPa}$ ) contributes to soil improvement, with increasing undrained shear stress of the reinforced soil. On the other hand, for high confinement stresses, the undrained shear stress of sandy material is more strongly decreased than that of gravel material.

Frikha et al. (2015) reported the influence of the number of columns and the confining stress on the mechanical characteristics of Tunis soft clay soil. Their paper presents the results of triaxial tests performed on Kaolin-type soft soil samples subjected to different confinement stresses. The reinforcement is performed using a different number of columns while keeping the substitution factor constant at a value close to $22 \%$. The obtained results showed that increasing the number of columns installed provides an improvement of the undrained shear strength and of the angle of internal friction. For example, the installation of a single insulated column increases the angle of internal friction by $37 \%$ as compared to unreinforced soil.

The spacing between the columns is also a key parameter that affects the performance of the stone column reinforcement. Ambily \& Gandhi (2007) conducted experimental tests based on axial loading by changing the ratio between column spacing and diameter. Their experimental results were then compared with finite element 
1 numerical simulations. It was found that the settlement of the reinforced soil decreases

2 the more the columns are spaced out. In addition, a series of stone columns spaced out

3 by more than three times their diameter does not significantly improve the soil

4 (undrained shear strength of the soil and the internal friction angle).

Most of the above presented studies only focused on one soil improvement

6 criterion, either bearing capacity or settlement. The investigations were also generally

7 limited to a single technique of reinforcement. The only recent contribution, to the

8 authors' best knowledge, where both criteria were addressed simultaneously is that

9 proposed by Bouassida, 2012 and Bouassida \& Carter, 2014. In fact, the objectives of

10 such a design column reinforcement are to achieve suitable load bearing capacity and

11 settlement reduction to some admissible values.

12 The study of soil behaviour reinforced by stone columns under oedometer

13 conditions is interesting because it corresponds to real situations in practice (large

14 embankment and large diameter reservoir) resting on a compressible layer reinforced by

15 stone columns on a height which is significantly less than the dimensions of the loaded

16 surface. Indeed, Tabchouche et al. (2017) studied the effect of reinforcement mesh

17 based on numerical computations.

18 In order to better interpret the experimental results, we sometimes resort to the

19 reconstitution of soft soils to fill its geotechnical parameters: homogeneity and water

20 content (Bouassida, 1996), to use analogical material with well controlled properties

21 (Frikha et al., 2014).

\subsection{Description of materials}

23 In this study, the "model" compressible soil is a granular material of the glass-bead type

24 with a poly-disperse granularity of less than $d_{\max }=50 \mu \mathrm{m}$. For the stone columns, two

25 granular materials obtained by dry sieving were chosen, namely quasi-spherical glass 
1 beads (GB) and crushed sand (CS). The particle size of these two materials lies between

$20.7 \mathrm{~mm}$ and $1.0 \mathrm{~mm}$. To characterize these materials, several tests were conducted in the 3 laboratory.

4

The specific dry mass $\rho_{s}$ of all used materials was determined using the pycnometer method (NF P94-054, 1991). The particles size curves (Fig. 1) were obtained using a method of optical microscopy photographic image processing that allows measurement of the different particle's diameters. Captured pictures were analysed by Image J Ops software (Rueden et al., 2017) and then treated by an algorithm of circle detection using the MATLAB software. The chosen granularity appears uniform and well graded.

The liquid limit $w_{L}$ for glass beads with a diameter less than $50 \mu \mathrm{m}$ (Fig. 2a) was determined using the cone penetrometer method (NF P94-052-1, 1995). According to this standard, only particles dimensions smaller than $400 \mu \mathrm{m}$ can be tested in the laboratory.

In order to determine the compaction reference values of glass beads smaller than $50 \mu \mathrm{m}$, standard Proctor tests (NF P94-093, 2014) were used. The results (Fig. 2b) give a maximum dry mass $\rho_{d O P N}=1920 \mathrm{~kg} / \mathrm{m}^{3}$ and an optimum water content $w_{O P N}=$ $12.7 \%$.

This work aims at studying the behaviour of a normally consolidated soil reinforced by stone column. In this objective, apparent dry mass $\rho_{d}=1350 \mathrm{~kg} / \mathrm{m}^{3}$ and initial water content $w_{0}=10 \%$ for glass beads smaller than $50 \mu \mathrm{m}$ have been chosen. An oedometer consolidation test was performed, which showed that the preconsolidation stress was nearly $\sigma_{p}^{\prime}=7 \mathrm{kPa}$ (Fig. 3a).

In order to determine the apparent dry mass $\rho_{d}$ of the column material during the set up without vibration and without compaction, columns were formed by filling metal 
1 tubes of $10 \mathrm{~mm}$ in diameter and different lengths $(120 \mathrm{~mm}, 150 \mathrm{~mm}, 170 \mathrm{~mm}$ and 200

$2 \mathrm{~mm}$ ) with material. The results showed that, under these installation conditions,

3 apparent dry mass of glass beads $0.7-1.0 \mathrm{~mm}$ is $\rho_{d}=1570 \pm 10 \mathrm{~kg} / \mathrm{m}^{3}$ and apparent

4 dry mass of crushed sand $0.7-1.0 \mathrm{~mm}$ is $\rho_{d}=1430 \pm 10 \mathrm{~kg} / \mathrm{m}^{3}$.

Direct shear box tests and shear strength tests with triaxial test apparatus were

6 carried out to determine the values for the internal friction angle $\phi$ and the cohesion $C$.

7 Those tests were performed under the same conditions as those used for the

8 experimental procedure for each material, namely:

Table 1 summarizes the characteristics of selected materials used in this study.

\section{Experimental protocol}

17 A spilt standard Proctor mould with its removable extension, which dimensions are height $\mathrm{H}=167.7 \mathrm{~mm}$ and diameter $\mathrm{D}=101.5 \mathrm{~mm}$, was used in order to observe the profile of the column height at the end of each test (Fig. 4).

In this mould, a quasi-spherical glass bead material smaller than $\mathrm{d}_{\max }=50 \mu \mathrm{m}$ is prepared at initial water content $w_{0}=10 \%$ and then compacted by a hydraulic press using a $10 \mathrm{~mm}$ thick compaction disk to achieve an apparent dry mass $\rho_{d}=1350 \mathrm{~kg} / \mathrm{m}^{3}$. 
1 The obtained soil sample in split standard Proctor mould has height $\mathrm{H}_{0}=157.7 \mathrm{~mm}$ and 2 diameter $\mathrm{D}_{0}=101.5 \mathrm{~mm}$ (Fig. 5).

The columns are installed by lateral displacement of soil using a steel rod made

4 of a $10 \mathrm{~mm}$ diameter tube, equipped with a removable conical tip at its base (Fig. 6a).

5 The diameter of the chosen tube gives a ratio of about ten between the diameter $\mathrm{D}_{\mathrm{c}}=$

$610 \mathrm{~mm}$ of stone column and the diameter $\mathrm{D}_{0}=101.5 \mathrm{~mm}$ of the soil to be reinforced in

7 the mould and thus to avoid edge effects. The upper part of prepared sample is covered

8 by a $10 \mathrm{~mm}$ thick cylindrical disc, then rod penetration by using MTS (Mechanical

9 Testing System) device is operated at constant speed $\mathrm{v}=0.01 \mathrm{~mm} / \mathrm{s}$ without vibration

10 and without air insufflation, up to the base of spilt standard Proctor mould. The conical

11 bottom side of the rod is withdrawn to install the dry constitutive material of stone

12 column. This material is introduced in successive $20 \mathrm{~mm}$ sub-layers by gradual

13 withdrawal of the tube until column length $\mathrm{L}_{\mathrm{c}}=157.7 \mathrm{~mm}$ is obtained (Fig. 6b). The

14 column material is placed without lateral expansion over its entire length.

In this study, the ratio between the length $\mathrm{L}_{\mathrm{c}}$ and column diameter $\mathrm{D}_{\mathrm{c}}$ equals

16 15.8. The solid particles of the stone column are assumed to be non-deformable. The

17 particle size of two materials was chosen to keep constant ratio of ten between the

18 diameter $D_{c}$ of the column and the largest grain size $D_{\max }=1 \mathrm{~mm}$, also constant ratio of

19 twenty is used between the largest soil grain diameter $\mathrm{d}_{\max }=0.05 \mathrm{~mm}$ and the largest

20 stone column grain diameter $\mathrm{D}_{\max }=1 \mathrm{~mm}$. The orders of magnitude are commonly

21 accepted in previous studies of soil reinforcement by stone columns using reduced-scale

22 models (Ambily \& Gandhi, 2007, Pivarč, 2011 and Sivakumar et al., 2004).

24 reinforcement configurations and related implementation procedure. 


\section{$1 \quad 2.1 \quad$ Installation of stone columns}

2 In this study, the placed columns simulate those resting on a rigid substratum (bottom of

3 the mould), their installation is performed by incorporating the material into the soil.

4

A hollow disc, according to the chosen mesh size, is placed at the top surface of the sample (Table 2). This disc simulates the embedding depth of the foundation loaded on the reinforced soil and allowing reduced vertical displacement around the loaded area. Rod penetration is guided by a cylinder, $10 \mathrm{~mm}$ thick perforated according to the chosen mesh.

In practice, the number of columns set up is expressed by the substitution factor $\eta$, which is defined by: $\eta=\frac{A_{c}}{A_{L}}$ where $A_{c}$ is the column section and $A_{L}$ is the section of the soil (loaded section).

In the case of reinforcement using the same material as the surrounding soil (glass bead material smaller than $\mathrm{d}_{\max }=50 \mu \mathrm{m}$ ), a piston of the same inside diameter as the tube is introduced to slightly compact each layer so that the column has an apparent dry mass $\rho_{\mathrm{d}}=1350 \mathrm{~kg} / \mathrm{m}^{3}$ identical to that of the soil, this step is repeated per layer until the column is completely filled.

To be able to evaluate the effect of reinforcement on the mechanical behaviour of the "Soil-Column" system, two families of samples are distinguished: the first, known as the "reference" family, corresponds to the non-reinforced case, the second set corresponds to the reinforced case either by an isolated column, or by a group of three or four columns arranged respectively at the vertices of an equilateral triangle of $24.51 \mathrm{~mm}$ and $30.00 \mathrm{~mm}$ sides, or a square of $24.54 \mathrm{~mm}$ or $20.00 \mathrm{~mm}$ sides. For each column configuration (triangle or square), the side length corresponds to the intercolumn distance. 


\section{$1 \quad 2.2 \quad$ Loading samples}

2 The MTS device, used for sample loading, is equipped with a force sensor and

3 displacement sensor connected to an acquisition system for recording data. Vertical

4 centred load of $3 \mathrm{kN}$ is applied by a rigid piston of $50 \mathrm{~mm}$ length, on the whole area of

5 soil sample (Fig. 6c).

In the case of reinforcement by a group of columns and for all considered

7 meshes, the loading area includes the entire group of columns installed.

\section{$8 \quad 3 \quad$ Interpretation of results and discussion}

9 The application of vertical loading results in a uniform vertical displacement of the

10 reinforced soil surface. The concentration of stress at the column level is explained by a

11 rigidity (Young's modulus) which is much higher than that of the surrounding soil. In

12 practice, the margin of values of Young's modulus of column materials is between 5 and

1310 times higher than that of Young's modulus of the soil to be reinforced in the non-

14 cohesive case with a friction angle between $35^{\circ}$ and $38^{\circ}$. For stone material with low

15 cohesion $5 \mathrm{kPa}<\mathrm{C}<10 \mathrm{kPa}$, and an internal friction angle greater than $38^{\circ}$, the Young

16 modulus equals 15 to 50 times the young modulus of initial soil (Bouassida, 2016).

17 The reinforcement of a compressible soil by stone columns requires the

18 knowledge of the following parameters (concentration ratio of vertical stress $n$,

19 substitution coefficient surface area $\eta$, and settlement reduction coefficient $\beta$ ).

Generally, the study of the reinforcement of a compressible soil carried out by

21 means of a scaled laboratory model (composite cell) simulates a full-scale case study

22 with a $1 / 20$ length scale. The case study corresponds in practice to a rigid foundation

$231 \mathrm{~m}$ in diameter resting on a compressible soil layer $3.16 \mathrm{~m}$ thick (Fig. 7). 
From Fig. 9, laboratory loading tests in oedometer condition showed that the

2 ultimate vertical stress equals to $1527 \mathrm{kPa}$. The load is subjected to tested samples by

3 circular rigid disk which models rigid shallow foundation with negligible embedment.

4 In such case, the admissible vertical stress is determined from the recorded ultimate

5 vertical stress divided by a factor of safety, against punching, $\mathrm{F}=3$. Therefore, it comes

6 the admissible stress value: $1527 / 3=509 \mathrm{kPa}$, reduced to $500 \mathrm{kPa}$.

7 In the following loading tests, the behaviour of the soil with respect to vertical

8 deformation is studied for vertical stresses less than $500 \mathrm{kPa}$, which is an admissible

9 stress (Fig. 8).

10 Figure 9 illustrates the effect of the installation of stone columns on Young's

11 modulus of unreinforced soil. Indeed, Young's modulus of the initial soil increases

12 starting at an axial deformation equal to $0.9 \%$ which corresponds to a vertical stress of

13 about $500 \mathrm{kPa}$.

14 The results of loading a single column reinforced soil $(\eta=4 \%)$ don't show the

15 effect of the reinforcement on the soil's behaviour towards settlement reduction, which

16 remains the main objective of column reinforcement (Fig. 10). This effect is due to the

17 very high rigidity of the initial soil. Indeed, according to Bouassida (2016), Young's

18 modulus of a compressible soil subject to stone column reinforcement is almost always

19 less than $10 \mathrm{MPa}$, which is not the case of the tested soil.

20 From an unconfined compression test, after the equations of linear elastic

21 behavior of isotropic material, the Young's modulus $E$ is determined as the ratio of

22 applied axial (vertical) stress $\sigma$ and the corresponding axial strain $\varepsilon$ ():

$23 \quad \mathrm{E}=\frac{\sigma}{\varepsilon}$ 
1 Because the samples are tested in oedometer condition, the horizontal stress is

2 determined from zero horizontal strain. Substituting those conditions in the linear elastic

3 Hooke's law for isotropic material, the oedometer modulus $\mathrm{E}_{\text {oed }}$ is determined from

4 Equation (2) as a function of the Poisson's ratio $v$ and Young's modulus of the soil E :

$5 \quad E_{\text {oed }}=\frac{(1-v)}{(1-2 v)(1+v)} \mathrm{E}$

6 In oedometer condition (zero horizontal strain), the settlement, denoted by s, is

7 expressed as a function of the oedometer modulus, the length of end-bearing columns $L_{c}$

8 and the applied vertical stress $\sigma$ :

$9 \quad \mathrm{~S}=\frac{L_{c}}{E_{\text {oed }}} \sigma$

10 Substituting Equation (2) in Equation (3), the Young modulus is deduced from

11 Equation (4) :

$12 \quad E=\frac{\sigma L_{c}(1-2 v)(1+v)}{(1-v) \mathrm{s}}$

The Young's modulus of reinforced soil as a function of the number of columns

14 (substitution factor) is presented in Figure 11. There is an increase in Young's modulus

15 with the number of installed columns. Indeed, the installation of a group of three and

16 four sand columns increased Young's modulus of the soil by $7.2 \%$ and $19.5 \%$

17 respectively.

18 A simple estimate, by default (Bouassida et al., 2003), of the Young's modulus

19 of reinforced soil is given by Equation (5).

$20 \quad E_{s r}^{h o m}=\eta E_{c}+(1-\eta) E_{s}$ 
2 estimated from Equation (5), are presented in Table 3:

4 Equation (5) are significantly overestimated compared to the values measured

5 experimentally. This can be explained by the ratio between Young's modulus of the soil

6 and that of the column (5 times), which remains low compared to the values used in

7 practice: this ratio is often higher than 10 times (Bouassida, 2016).

\section{$8 \quad 3.1 \quad$ Influence of the reinforcing material}

9 To study the effect of the installation of stone columns on the mechanical characteristics of the soil before and after reinforcement, the settlement of unreinforced and reinforced samples are compared under the same vertical stress of $1.53 \mathrm{MPa}$ subjected to circular area of $50 \mathrm{~mm}$ diameter maintained for the same duration of 25 hours reach constant axial strain.

For a substitution factor $\eta=12 \%$, the loading results clearly show the improvement made to the soil with this installation. At a vertical stress of $500 \mathrm{kPa}$, there is a $5.75 \%$ increase in the load-bearing capacity of the reinforced soil, for a substitution factor $\eta=16 \%$, as compared to the initial soil (Fig. 12).

In this study, the effect of the installation of the columns, and in particular the backflow drilling, causes an increase in the density of the surrounding soil of $3.88 \%$ for a single column. This phenomenon of densification increases the load-bearing capacity of the surrounding soil by decreasing the void ratio (Tab. 4) and, consequently, an increase in the Young's modulus of the initial soil (Guetif et al., 2007).

To show the effect of this densification on the interaction between the column and the surrounding soil, a column filled with the same soil material (glass beads $<50$ $\mu \mathrm{m}$ and with the same water content $w_{0}=10 \%$ ) was installed. It can be seen that the 
1 variation of axial strain for reinforced soil with a column filled with the same material

2 from the initial soil is identical to that of the "reference" soil.

Obtained results show a $20 \%$ increase in column diameter over a depth equal to

4 three (3) times the column diameter (Fig. 13a and Fig. 13b). Thus, a slight decrease in

5 the column diameter is observed beyond this depth. This "local contraction" lateral

6 expansion is explained by a significant confining stress exerted by the surrounding soil

7 to the column. This highlights the importance of the load transfer mechanism between

8 the installed column and the surrounding soil . Generally, this lateral expansion is

9 exerted from the column towards the surrounding soil, since the column is a bearing

10 component of the foundation (Fig. 13c).

11 This lateral expansion is plotted as a function of depth in Figure 14:

12 During sample preparation, the variation of the void ratio was recorded before

13 and after the drilling operation as well as during loading test. The void ratio $e$ is equal to

14 to the volume of voids $V_{v}$ by the volume of soil grains $V_{s}\left(e=\frac{V_{v}}{V_{s}}\right)$.

15 During loading, the variation of the void ratio depends linearly on the axial

16 strain of tested sample.

17 This decrease in void ratio during reinforcement from drilling to column

18 loading is a very important indicator that shows the beneficial effect of reinforcement

19 on soil density. Figure 15 shows that the void ratio decreases when the substitution

20 factor is increased (Fig. 15).

21 To evaluate the choice between rolled (glass beads) or crushed (sand) stone, an

22 external vibration system was introduced for filling the column with crushed sand so

23 that its apparent dry mass becomes similar to that of the glass beads $\left(1523 \mathrm{~kg} / \mathrm{m}^{3}\right)$ (Fig.

24 16). 
2 soil properties much better, rather than using crushed sand, this well illustrates the

3 effect of the angle of internal friction of the added material. Indeed, the angle of internal

4 friction of a rolled material is lower than that of a crushed material, which facilitates a

5 better rearrangement of the grains during filling and thus promotes a better dry density

6 of the reinforced soil. For a vertical stress of $500 \mathrm{kPa}$, Young's modulus of the soil

7 reinforced with a rolled material (glass beads) is $12.25 \%$ higher than that of a soil

8 reinforced with a crushed material (crushing sand).

\section{$9 \quad 3.2 \quad$ Effect of the substitution factor and the soil-column contact interface}

10 In this case, the samples of the initial soil are reinforced by respectively a single

11 column, three and four columns corresponding to a substitution factor of respectively

$124 \%, 12 \%$ and 16\%. Measurements of axial deformation during loading (Fig. 17)

13 illustrate the effect of the substitution factor on soil improvement with respect to

14 bearing capacity.

The interface between the added material (ballast) and the initial soil is a key parameter that can affect the effectiveness of the reinforcement. The samples tested have a contact surface (interface) of 25,74 and $100 \mathrm{~cm}^{2}$ respectively for one column, three columns (placed at the top of an equilateral triangle) and four columns (placed at

19 the top of a square).

It is clear that the effect of the soil-column contact interface is the same with

21 respect to the substitution factor. Indeed, as the soil-column contact area increases,

22 Young's modulus of the soil also increases (Fig. 18).

The soil-column contact interface $A_{\text {cont }}$ can be expressed in terms of the

24 substitution factor $\eta$ using Equation 6: 
$1 \quad A_{\text {cont }}=25 \pi L_{c} \eta$

2 According to Equation (6), once the substitution factor $\eta$ is determined, the soil-

3 column contact interface depends only on the length of the installed column.

\section{$4 \quad 3.3 \quad$ Effect of the installation of the columns: with or without vibration}

5 There are two methods of placing (installing) the columns: with vibration or without

6 vibration (standard track), however, it is interesting to check the effect of vibration

7 when filling the column material. For example, according to experience, the sand is a

8 granular material that by vibration.

However, the effect of vibrations can sometimes be harmful. In practice, the most economical method to compact a sand layer is to apply vibrations in a cyclic mode

11 at low frequency of 25 to 2500 cycles per minute (Terzaghi \& Peck, 1967).

In this study, the vibration process is performed from outside the sample when the column is filled by an electric sieve shaker, set at a low frequency. The filling is carried out as explained in the experimental protocol low frequency from 25 to 2500 cycles per minute. This technique is inspired by the process of placing sand piles (Fig. 19) installed to reinforce the Tunis mud during a project to build a large reservoir

17 (Bouassida \& Klai, 2012).

18 The tests carried out during the laboratory experiment showed that with this

19 vibration system the apparent dry mass of the columns increases by $1.1 \%$.

The axial strain of the samples reinforced with a single column of crushed sand

$210.7-1.0 \mathrm{~mm}$ is monitored for both vibration and non-vibration installation cases; the 22 results are presented in Figure 20. 
It should be noted that the application of a vibration system when filling a sand

2 column contributes to the increase in load-bearing capacity. This also results in a $22 \%$

3 increase in Young's modulus compared to a vibration-free installation.

5 rearrangement of the grains of the glass beads so that they occupy the smallest possible

6 volume. This process, therefore, acts by increasing the density in place and,

7 consequently, reducing the void ratio. However, since the crushed sand is clean and

8 non-cohesive, and therefore free of fine particles, the axial strain is almost

9 instantaneous, unlike axial strain caused by vibration in clay which remains weak

10 because of the cohesion that develops between the particles of the clay.

\section{$11 \quad 3.4$ Columns spacing}

12 The most important step in a reinforcement technique is to decide the suitable spacing

13 between the stone columns. Columns' spacing is linked to the substitution factor, thus it 14 controls the bearing capacity of reinforced soil (Bouassida et al, 1995). Two columns

15 patterns have been considered with varied spacing between columns. Three values of

$16 \mathrm{~s} / \mathrm{D}$ ratio (spacing between columns axis/ Column diameter) were considered: $\mathrm{s} / \mathrm{D}=$

$172.00, \mathrm{~s} / \mathrm{D}=2.45$ and $\mathrm{s} / \mathrm{D}=3.00$. The obtained results are presented in Figure 21. From

18 this figure, it can be seen that the axial strain reinforced by a group of columns, depends

19 on the spacing between the columns in triangular and square patterns. Indeed, the less is

20 columns' spacing the more is the stiffness of the initial soil.

Indeed, the interaction mechanism between the columns and the volume of the

22 surrounding soil is the main element which influences the behavior of reinforced soil,

23 seen only through this zone where there is an increase in horizontal stress that is related

24 to the interaction of the domains of influence of each column. 
2 located at the summits of an equilateral triangle) for which each column has an area of

3 influence presented by a circle of a given diameter (Table 5). It is concluded that the

4 mutual interaction between these influence zones in a tight spacing creates a mutual

5 zone of stress concentration. This part of initial soil behaves as a denser virtual column

6 which contributes to the improvement of bearing capacity of initial soil.

$7 \quad$ Ellouze et al. (2017) explained such interaction between the zones of influence

8 of a central column and surrounded by six columns installed in a triangular pattern (Fig.

9 24). This area of improved initial soil should be considered to predict an optimized

10 substitution factor for suitable design of reinforcement y columns.

\section{Conclusions}

12 In this paper, experimental investigation of the behaviour of reinforced soil by stone

13 columns was studied. The presented experimental tests constitute a contribution to

14 identify the effect of introducing vibrations when installing sand columns in an

15 analogical soil constituted by poly-dispersed glass beads of dimension smaller than

$1650 \mu \mathrm{m}$. The number and spacing between the columns as well as the choice of the type

17 of filler material (crushed or rolled stone) are parameters that remain poorly controlled

18 in the design of the reinforcement by stone columns. The results obtained from tests

19 carried out on - scaled models lead to the following conclusions:

- The use of rolled material is preferable to crushed material in improving the load-bearing capacity of the soil (the density of a column filled by a rolled material is greater (by 12.5\%) than that obtained for filled crushed material.

- The axial strain of reinforced soil decreases when increasing the number of installed columns. 
10 Results of the present study are straight forward applicable for the vibrocompacted

- The use of vibration method for column installation is recommended for better reinforcement performance (in terms of bearing capacity).

- Decreasing the spacing between columns, for a given columns arrangement, increases the load-bearing capacity of the soil. Column spacing controls the optimization of incorporated reinforcing material;

- The use of a vibration system, for columns' installation, increases Young's modulus of the initial soil by $22 \%$ as compared to a vibration-free installation;

- The improvement due to the reinforcement (increase in bearing capacity) increases with the number of installed columns. stone columns with or without added material.

Results of this experimental study are in progress for simulating the behaviour of a soil reinforced with full-scale stone columns using Plaxis software for FEM studies and specific software based on discrete element method. Therefore, the complex interaction between the column and the soil can be discussed in details, later on. 


\section{References}

Adalier, K., Elgamal, A., Meneses, J., \& Baez, J. I. (2003). Stone columns as liquefaction countermeasure in non-plastic silty soils. Soil Dynamics and Earthquake Engineering, 23(7), 571-584. https://doi.org/10.1016/S02677261(03)00070-8

Adalier, K., \& Elgamal, A. (2004). Mitigation of liquefaction and associated soil deformations by stone columns. Engineering Geology, 72(3-4), 275-291. https://doi.org/10.1016/j.enggeo.2003.11.001

Ambily, A. P., \& Gandhi, S. R. (2007). Behaviour of Stone Columns Based on Experimental and FEM Analysis. Journal of Geotechnical and Geoenvironmental Engineering, 133(4), 405-415. https://doi.org/10.1061/(ASCE)1090-0241(2007)133:4(405)

Andreou, P., Frikha, W., Frank, R., Canou, J., Papadopoulos, V., \& Dupla, J.-C. (2008). Experimental study on sand and gravel columns in clay. Proceedings of the Institution of Civil Engineers - Soil Improvement, 161(4), 189-198. https://doi.org/10.1680/grim.2008.161.4.189

BenSalem, Z., Frikha, W., \& Bouassida, M. (2017). Effects of Densification and Stiffening on Liquefaction Risk of Reinforced Soil by Stone Columns. Journal of Geotechnical and Geoenvironmental Engineering, 143(10), 1-6. https://doi.org/10.1061/(ASCE)GT.1943-5606.0001773.

Bouassida,M, De Buhan P., \& Dormieux L. (1995). Bearing capacity of foundation resting on a soil reinforced by a group of columns. Geotechnique, 45 (1), 25-34. https://doi.org/10.1680/geot.1995.45.1.25

Bouassida, M. (1996). Étude expérimentale du renforcement de la vase de Tunis par colonnes de sable - Application pour la validation de la résistance en compression théorique d'une cellule composite confinée. Revue Française de Géotechnique, 75, 3-12. https://doi.org/10.1051/geotech/1996075003

Bouassida, M., Guetif, Z., De Buhan, P., \& Dormieux, L. (2003). Estimation par une approche variationnelle du tassement d'une fondation sur sol renforcé par colonnes. Revue Française de Géotechnique, 102, 21-29. https://doi.org/10.1051/geotech/2003102021

Bouassida, M. (2012). Soil Improvement Case Histories and Advances in Practice. Proceedings of the International Conference on Soil Improvement and Soil 
Control : ICGI 30 October-2 November Wollongong, 1(1), 599-608. https://doi.org/10.3850/978-981-07-3559-3

Bouassida, M., \& Klai, M. (2012). Challenges and Improvement Solutions of Tunis Soft Clay. Int. J. of GEOMATE, Sept., 2012, Vol. 3, N. 1(SI. No 5), 298-307 Geotec., Const. Mat et Env., ISSN:2186-2982(P), 2186-2990(O), Japan.

Bouassida, M., \& Carter, J. P. (2014). Optimization of Design of Column-Reinforced Foundations. International Journal of Geomechanics, 14(6), 1-10 https://doi.org/10.1061/(ASCE)GM.1943-5622.0000384

Bouassida, M. (2016). Design of column-reinforced foundation (Ross, J.). ISBN 978-160427-072-3. 240 pages.

Castro, J., \& Sagaseta, C. (2011). Consolidation and deformation around stone columns: Numerical evaluation of analytical solutions. Computers and Geotechnics, 38(3), 354-362. https://doi.org/10.1016/j.compgeo.2010.12.006

Corneille, S. (2007). Etude du comportement mécanique des colonnes ballastées chargées par des semelles rigides. PhD Thesis. Institut National Polytechnique de LORRAINE, École Nationale Supérieure de Géologie de Nancy.

Ellouze, S., Bouassida, M., Bensalem, Z., \& Znaidi, M. N. (2017). Numerical analysis of the installation effects on the behaviour of soft clay improved by stone columns. Geomechanics and Geoengineering, 12(2), 73-85. https://doi.org/10.1080/17486025.2016.1164903

Fattah, M. Y., Al-Neami, M. A., \& Shamel Al-Suhaily, A. (2017). Estimation of bearing capacity of floating group of stone columns. Engineering Science and Technology, an International Journal, 20(3), 1166-1172. https://doi.org/10.1016/j.jestch.2017.03.005

Frikha, W., Bouassida, M., \& Canou, J. (2013). Observed Behaviour of Laterally Expanded Stone Column in Soft Soil. Geotechnical and Geological Engineering, 31(2), 739-752. https://doi.org/10.1007/s10706-013-9624-8

Frikha, W., Bouassida, M., \& Canou, J. (2014). Parametric Study of a Clayey Specimen Reinforced by a Granular Column. International Journal of Geomechanics, 15(5), 1-12. https://doi.org/10.1061/(ASCE)GM.1943-5622.0000419

Frikha, W., Tounekti, F., Kaffel, W., \& Bouassida, M. (2015). Experimental study for the mechanical characterization of Tunis soft soil reinforced by a group of sand columns. Soils and Foundations, 55(1), 181-191. https://doi.org/10.1016/j.sandf.2014.12.014 
1 Guetif, Z., Bouassida, M., \& Debats, J. M. (2007). Improved soft clay characteristics due to stone column installation. Computers and Geotechnics, 34(2), 104-111. https://doi.org/10.1016/j.compgeo.2006.09.008

Hasan, M. Bin, Marto, A. B., Hyodo, M., \& Makhtar, A. M. Bin. (2011). The strength of soft clay reinforced with singular and group bottom ash columns. Electronic Journal of Geotechnical Engineering, 16, 1215-1227. http://umpir.ump.edu.my/id/eprint/12004

Isaac, D. S., \& Girish, M. S. (2009). Suitability of different materials for stone column construction. Electronic Journal of Geotechnical Engineering, 14 M, 1-12. www.ejge.com/2009/Ppr09108.pdf

McCabe, B. A., Nimmons, G. J., \& Egan, D. (2009). A review of field performance of stone columns in soft soils. Proceedings of the Institution of Civil Engineers Geotechnical Engineering, 162(6), 323-334. https://doi.org/10.1680/geng.2009.162.6.323

Najjar, S., Sadek, S., \& Tarek, M. (2010). Effect of Sand Columns on the Undrained Load Response of Soft Clays. Journal of Geotechnical and Geoenvironmental Engineering, 136(9), 1263-1277. https://ascelibrary.org/doi/abs/10.1061/(ASCE)GT.1943-5606.0000328

Pivarč, J. (2011). Stone Columns - Determination of the soil improvement factor. Slovak Journal of Civil Engineering, 19(3), 17-21. https://doi.org/10.2478/v10189-011-0014-Z

Priebe, H. J. (1995). The design of vibroreplacement. Technical Paper: Soil Engineering, GT 07-13 E.

Rangeard, D., Phan, P. T. P., Martinez, J., \& Lambert, S. (2016). Mechanical behaviour of fine-grained soil reinforced by sand columns: An experimental laboratory study. Geotechnical Testing Journal, 39(4), 648-657. https://doi.org/10.1520/GTJ20150152

Rueden, C., Dietz, C., Hiner, M., Schindelin, J., N., Northan, B., Berthold, M., \& Eliceiri, K. (2017). Image J2: ImageJ for the next generation of scientific image data. BMC Bioinformatics, 18, 1-26. Retrieved from http://imagej.net/Ops

Shahu, J. T., \& Reddy, Y. R. (2011). Clayey Soil Reinforced with Stone Column Group: Model Tests and Analyses. Journal of Geotechnical and Geoenvironmental Engineering, 137(12), 1265-1274. https://doi.org/10.1061/(ASCE)GT.1943-5606.0000552 
1 Sivakumar, V., McKelvey, D., Graham, J., \& Hughes, D. (2004). Triaxial tests on

2

3

4

5

6 7 model sand columns in clay. Canadian Geotechnical Journal, 41(2), 299-312. https://doi.org/10.1139/t03-097

Soyez, B. (1985). Méthodes de dimensionnement des colonnes ballastées. Bulletin de liaison des Laboratoires des Ponts et Chaussées (Vol. 135).

Tabchouche, S., Mellas, M., \& Bouassida, M. (2017). On settlement prediction of soft clay reinforced by a group of stone columns. Innovative Infrastructure Solutions, 2(1). https://doi.org/10.1007/s41062-016-0049-0

Terzaghi, K., \& Peck, R. B. (1967). Soil Mechanics in Engineering Practice, (2nd Edition).

Vautrain, J. (1980). Comportement et dimensionnement des colonnes ballastées. Revue Française de Géotechnique, 11, 59-73. https://doi.org/10.1051/geotech/1980011059

Zahmatkesh, A., \& Choobbasti, A. J. (2010). Settlement Evaluation of Soft Clay Reinforced by Stone Columns, Considering the Effect of Soil Compaction. International Journal of Recent Research and Applied Studies, 3(May), 159166. 
Figure 1. Particle size curves of materials used.

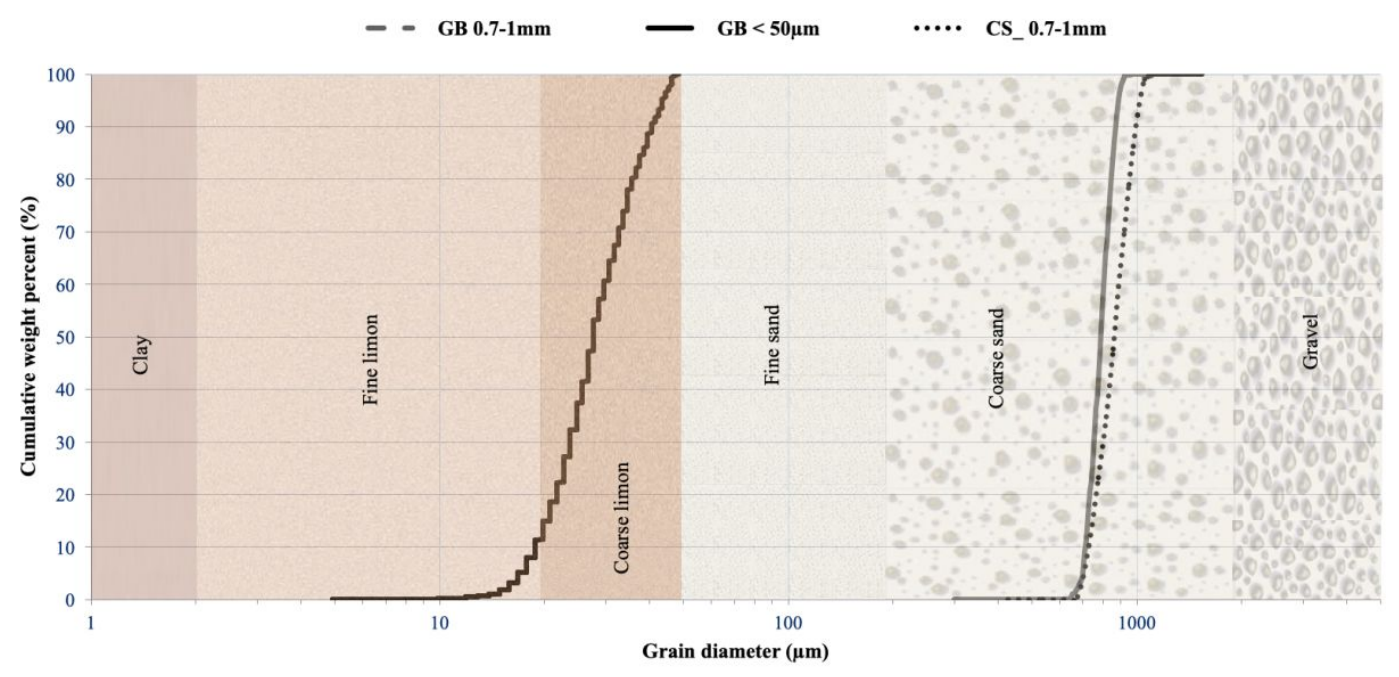


Figure 2. (a) Liquid limit and (b) standard Proctor curve of glass beads $<50 \mu \mathrm{m}$ using the cone penetrometer method.

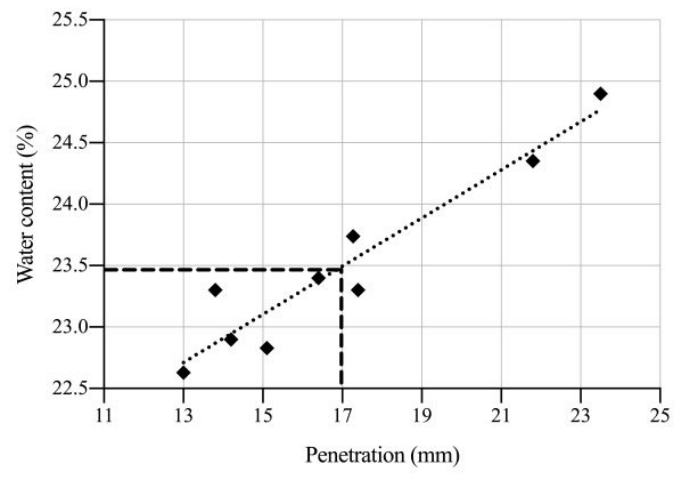

(a)

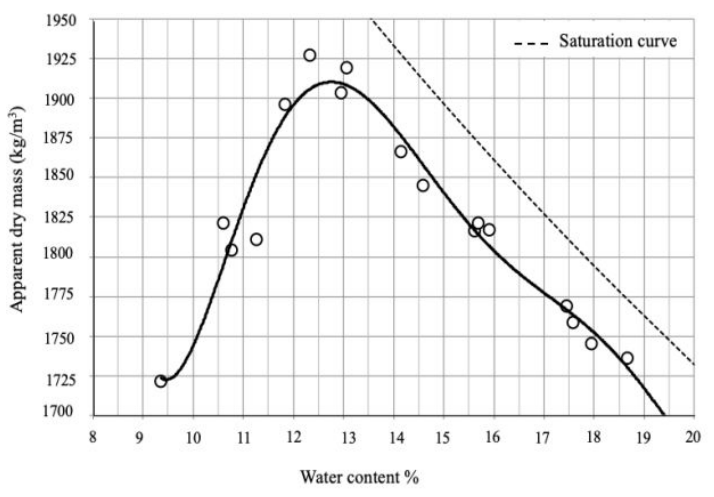

(b) 
Figure 3. (a) Oedometer curve and (b) direct and triaxial shear tests for glass beads $<50$ $\mu \mathrm{m}$.

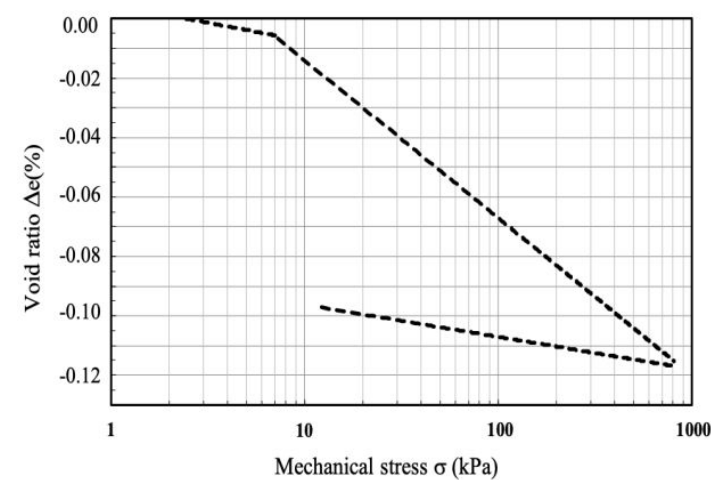

(a)

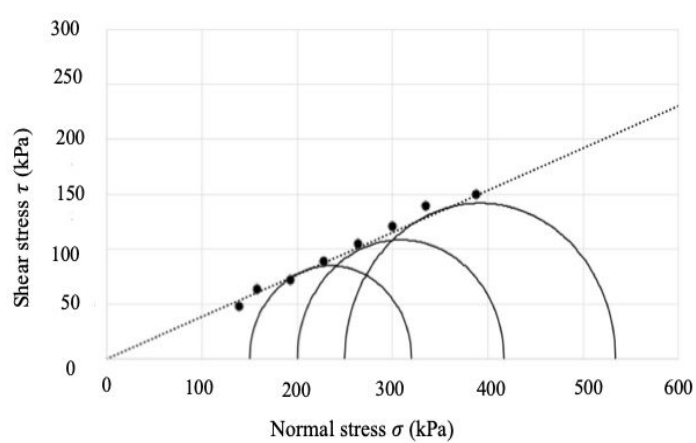

(b) 
Figure 4. Cutting of samples after loading and measurement of column diameter.
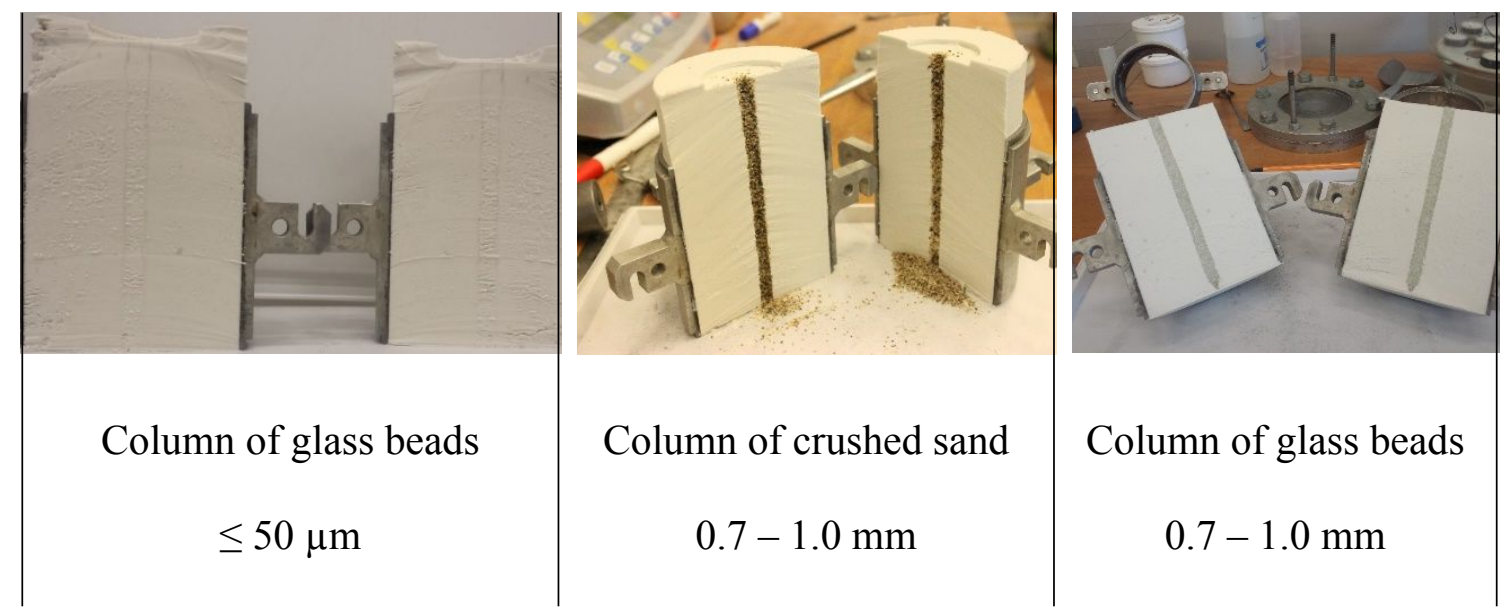
Figure 5. (a) Geometry and (b) picture of the spilt standard Proctor mould used for experimental testing.

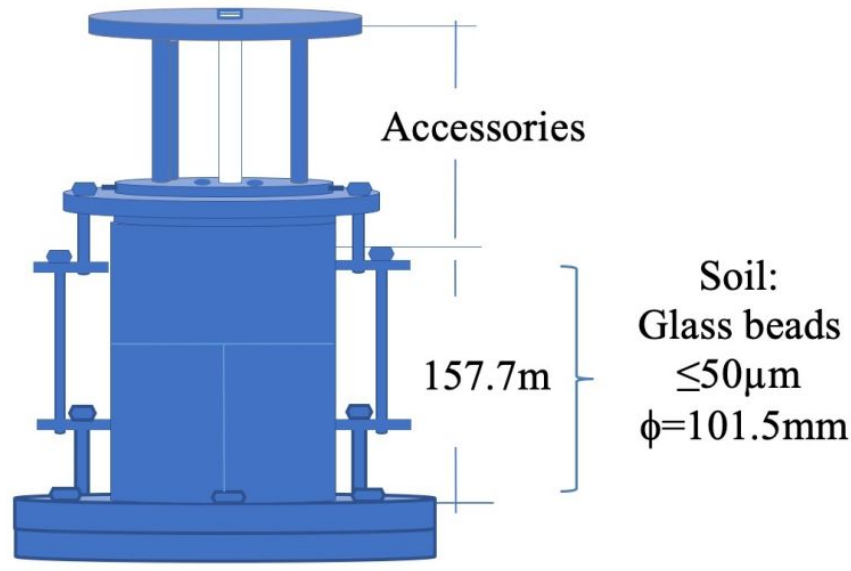

(a)

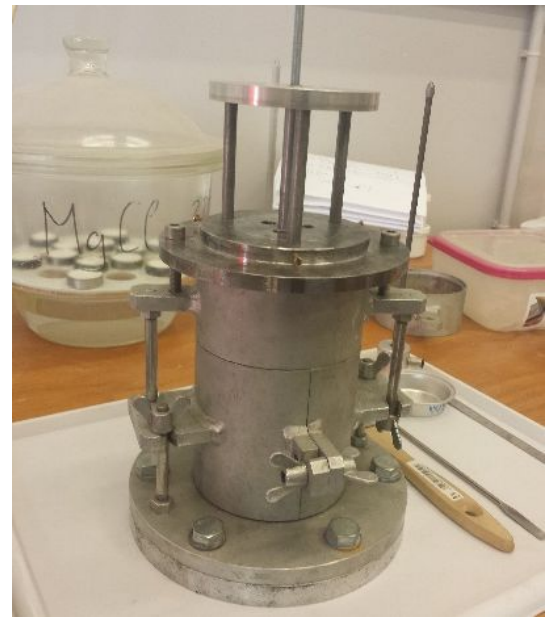

(b) 
Figure 6. Columns Installation (a) tube penetration (b) added matériel (c) loading process.

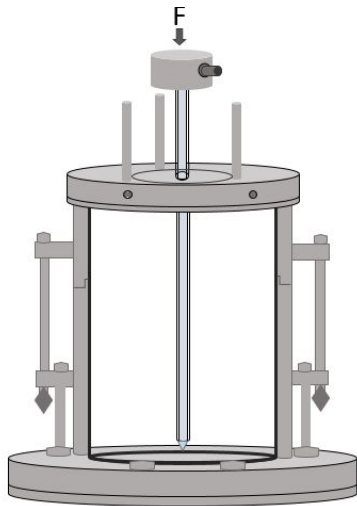

(a)

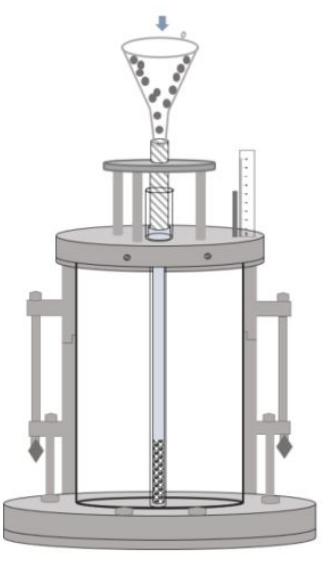

(b)

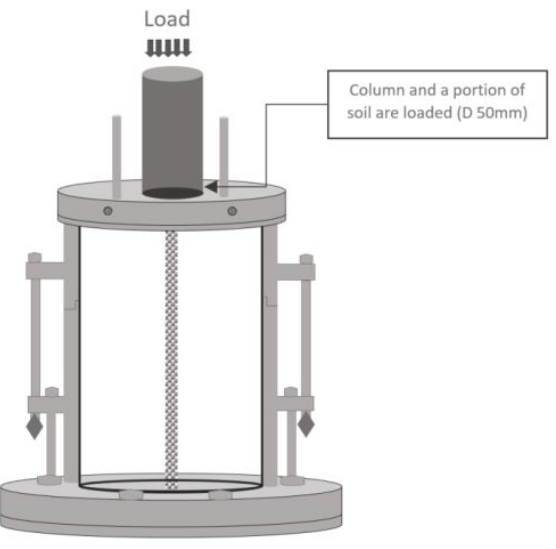

(c) 
Figure 7. (a) Correspondence between the scaled model (laboratory) and (b) full-scale model (dimensions in $\mathrm{mm}$ ).

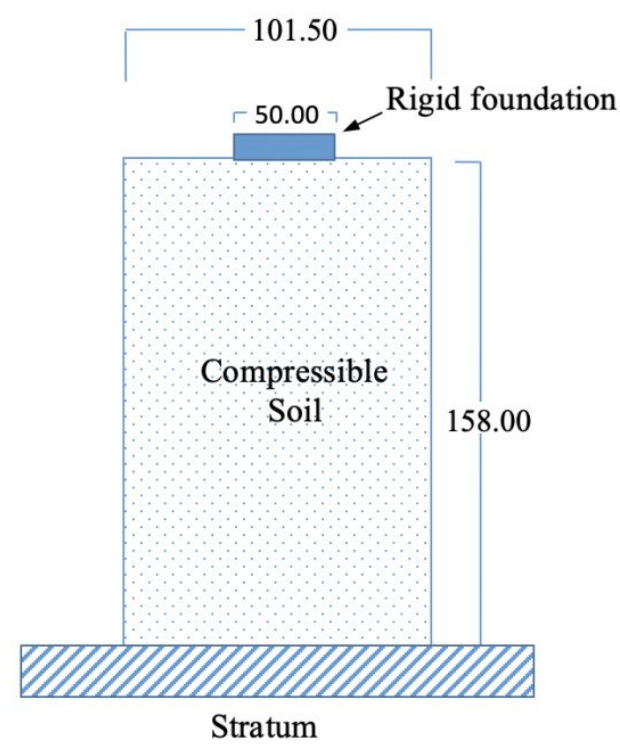

(a)

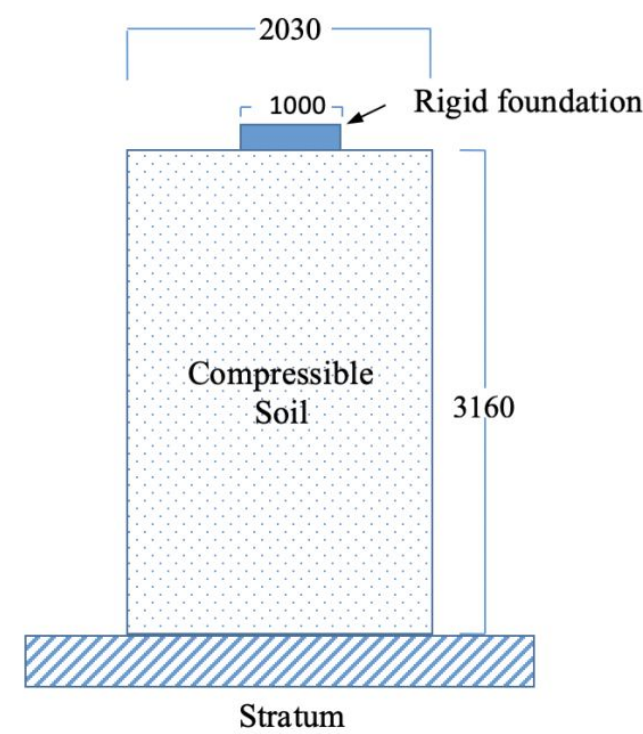

(b) 
Figure 8. Range of admissible vertical stress of unreinforced soil.

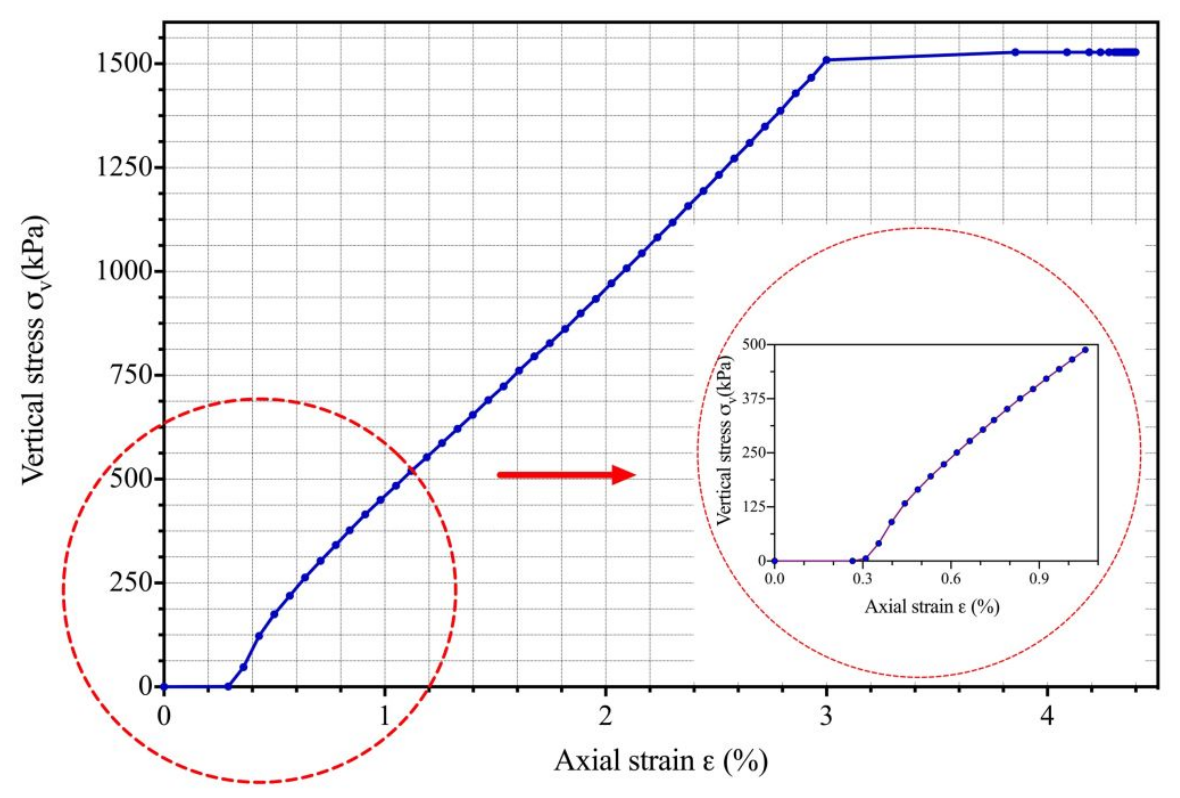


Figure 9. Variation of vertical stress versus axial deformation of soil reinforced by group of columns.

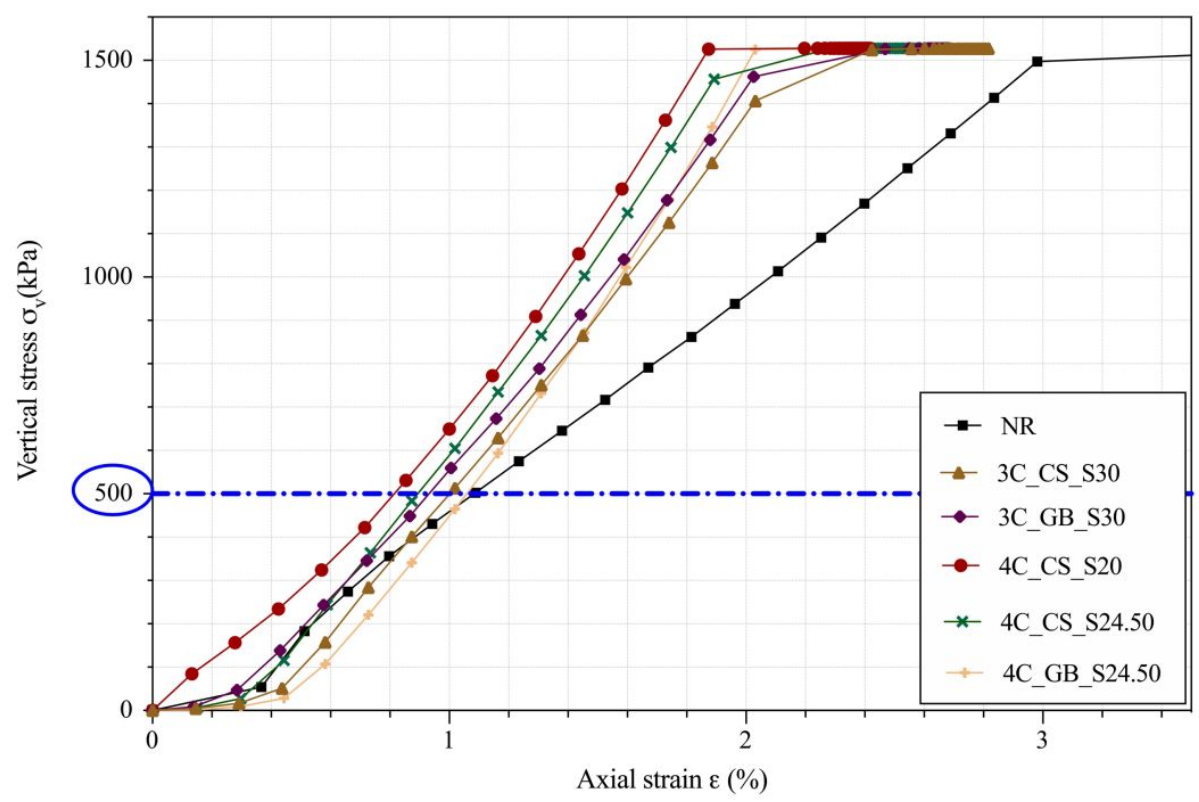


Figure 10. Evolution of vertical stress versus axial deformation $\eta=4 \%$.

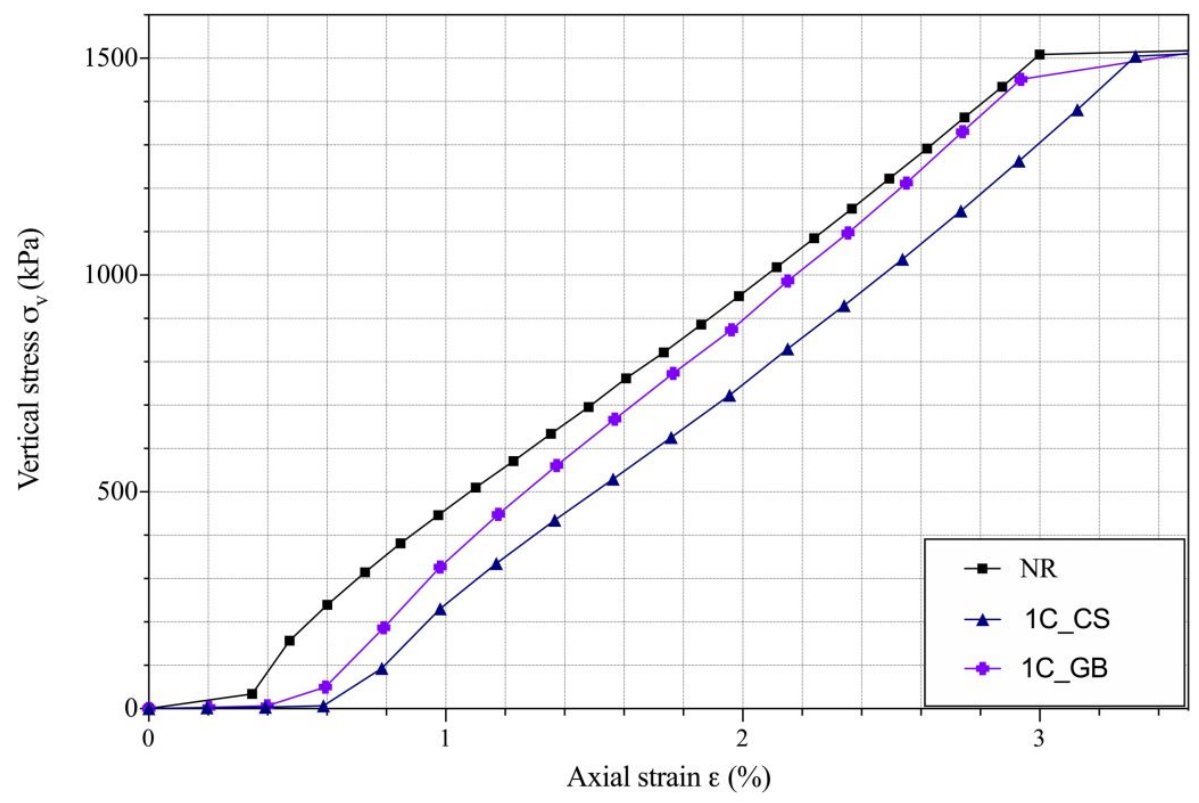


Figure 11. Variation of Young's modulus of reinforced soil versus the substitution factor.

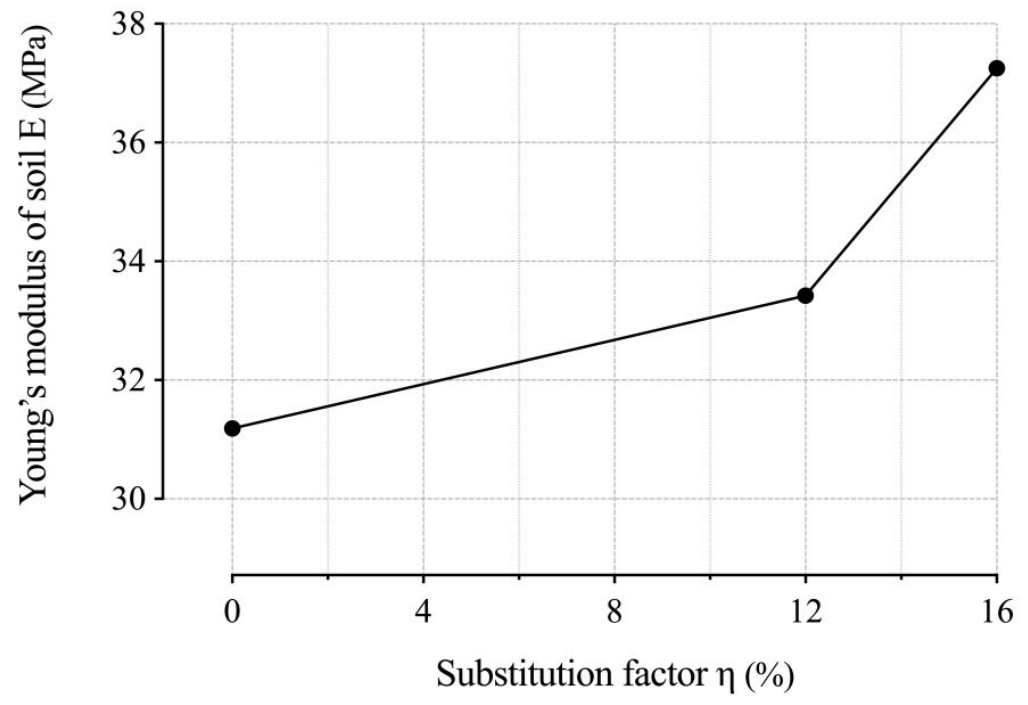


Figure 12. Variation of axial deformation of reinforced samples with four columns of crushed sand $0.7-1.0 \mathrm{~mm}$.

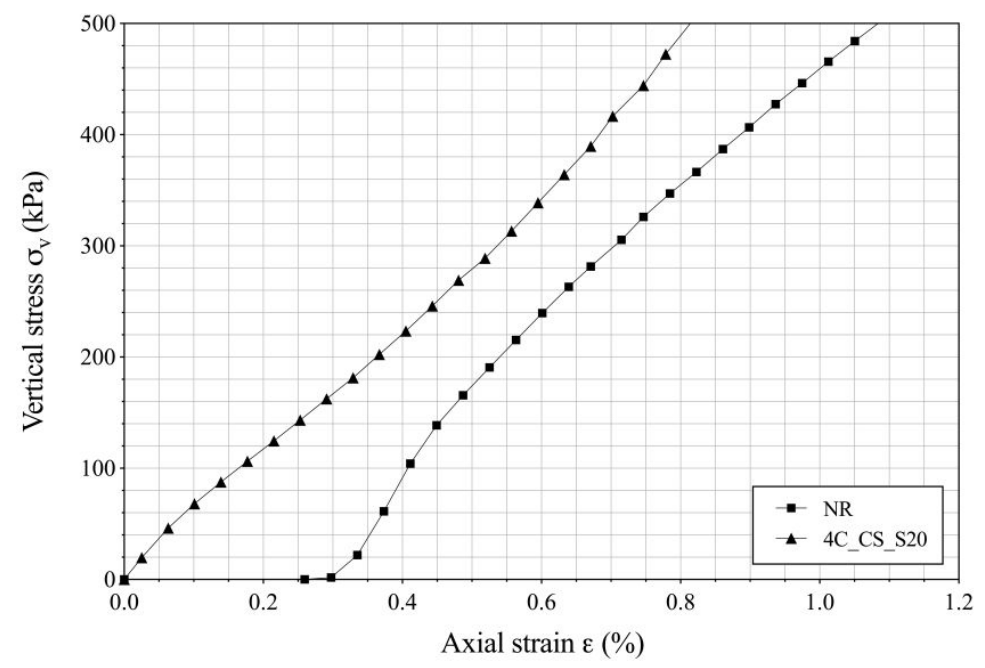


Figure 13. Illustration of the densification of surrounding soil: a) and b) are photos taken after loading and cutting samples, c) lateral expansion area .

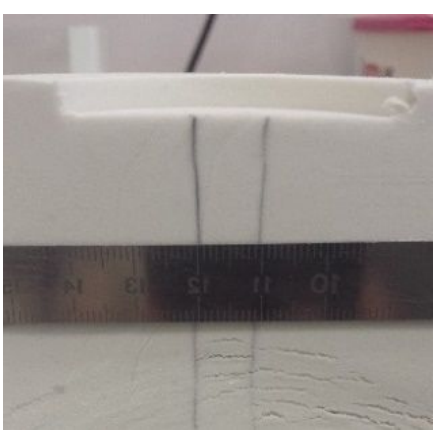

(a)

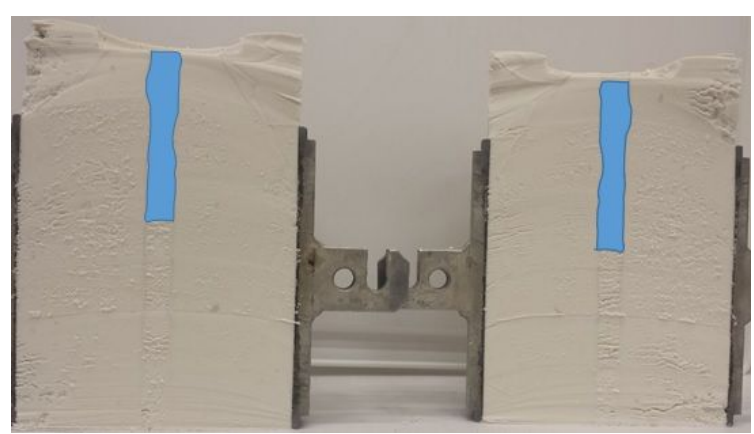

(b)

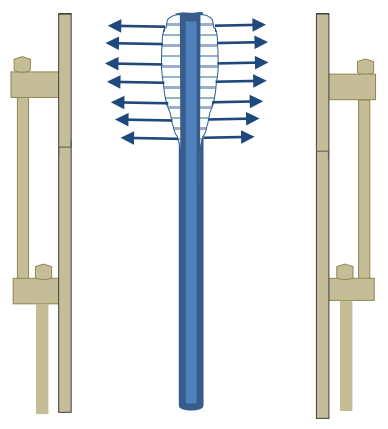

(c) 
Figure 14. Variation of the column diameter as a function of depth.

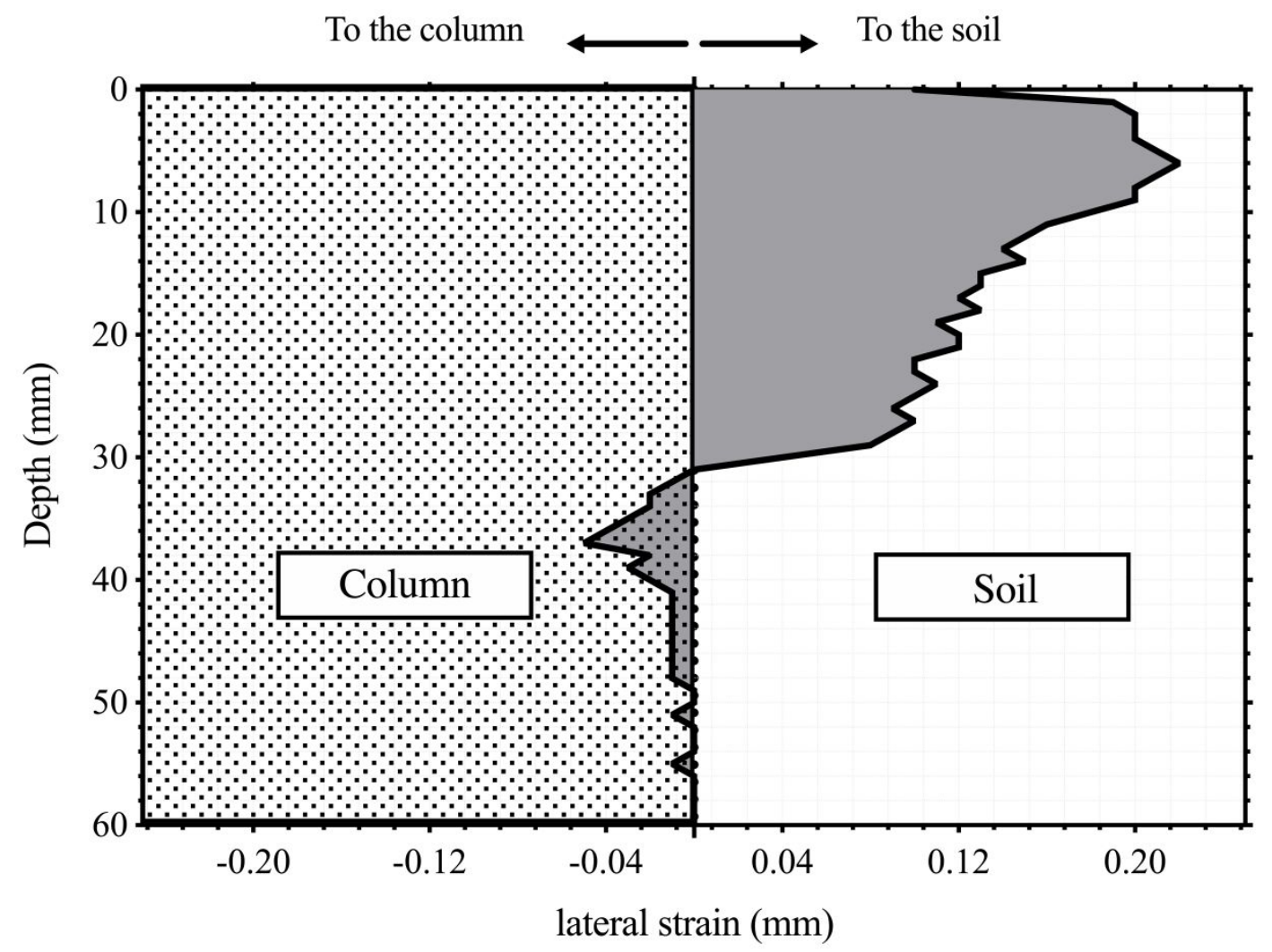


Figure 15. Evolution of void ratio as a function of substitution factor.

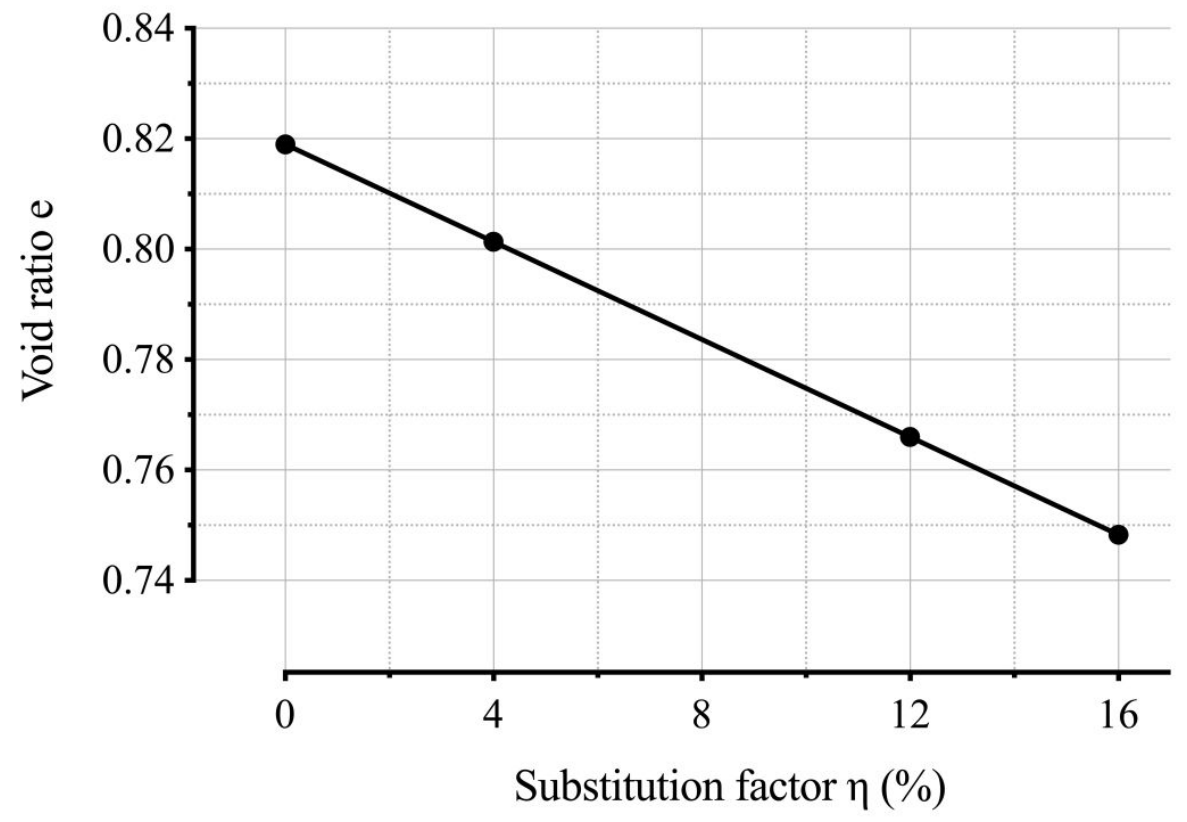


Figure 16. Influence of column material type (rolled or crushed) on the load-bearing capacity of reinforced soil.

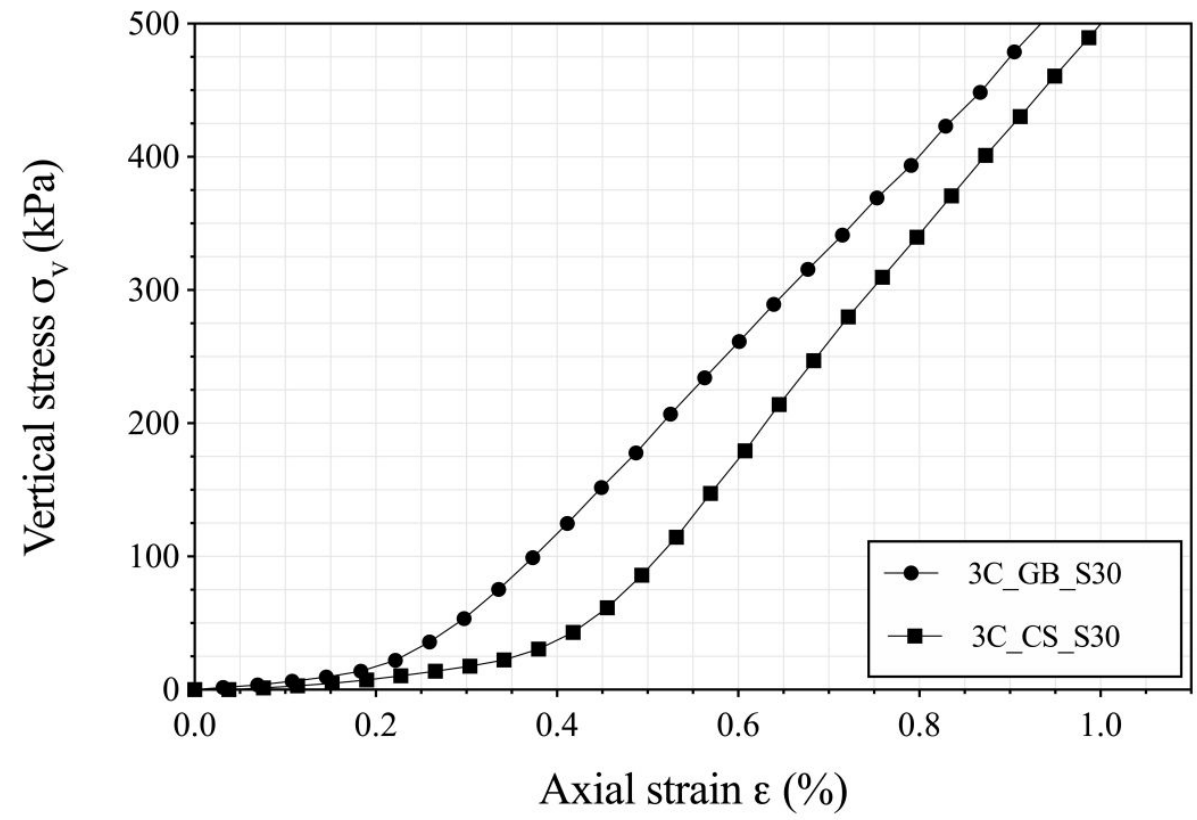


Figure 17. Influence of substitution factor on the load-bearing capacity of reinforced soil.

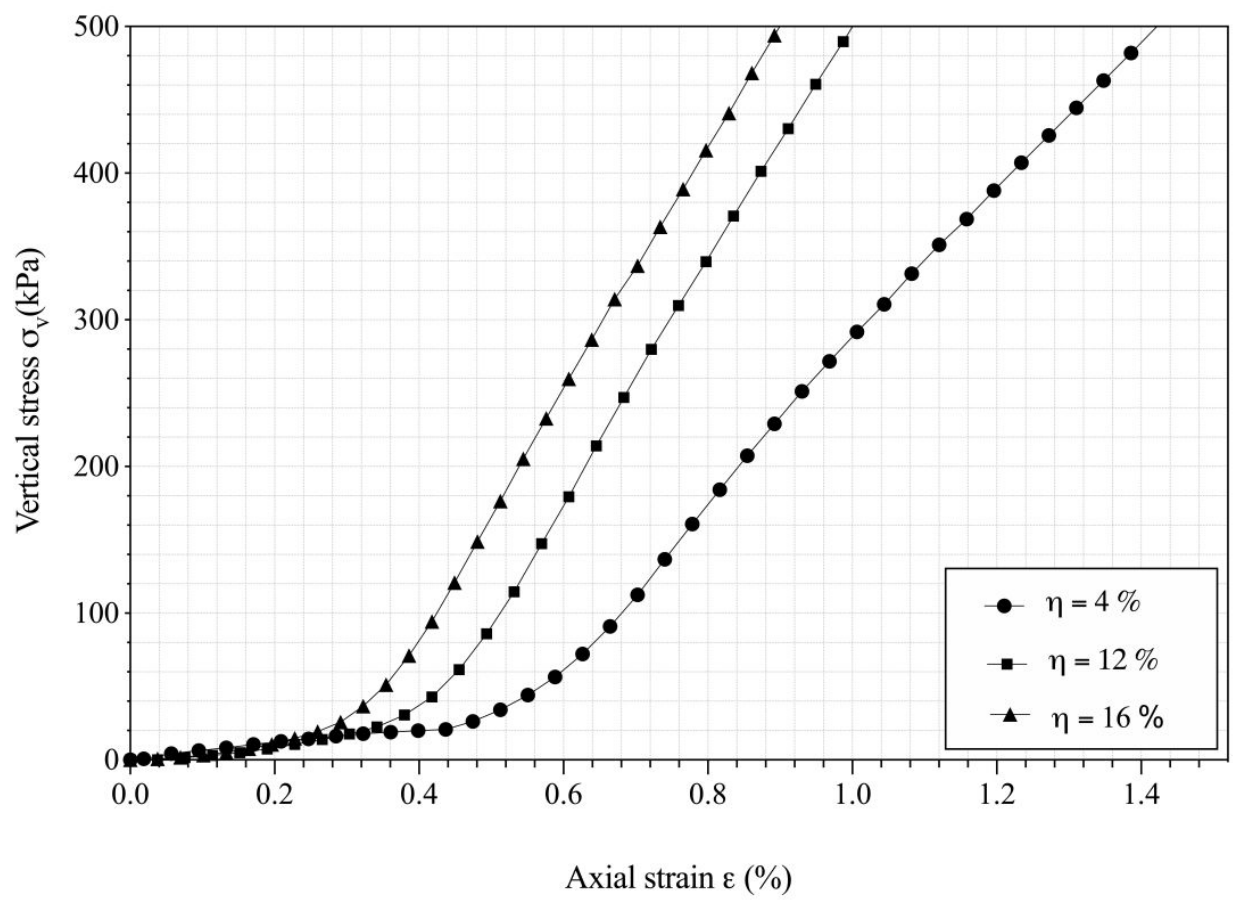


Figure 18. Influence of the soil-column contact surface (interface) on Young's modulus of reinforced soil.

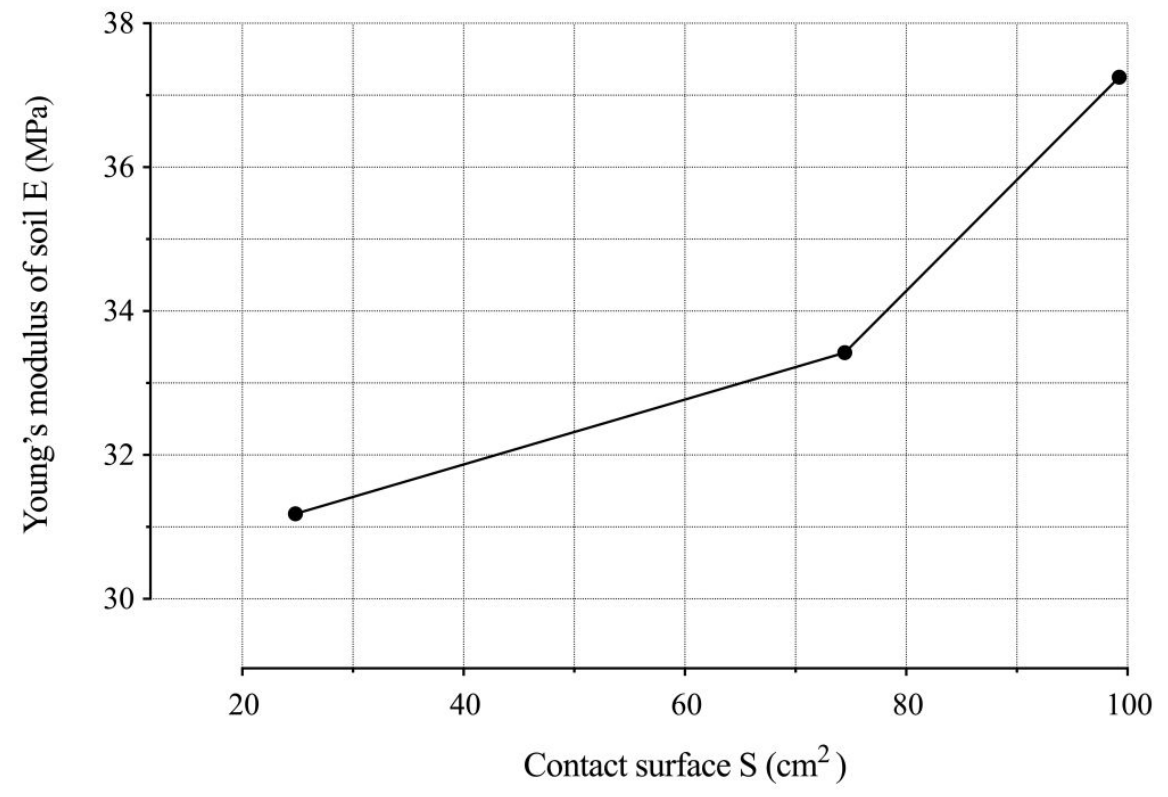


Figure 19. Installation of sand piles (Bouassida \& Klai, 2012).

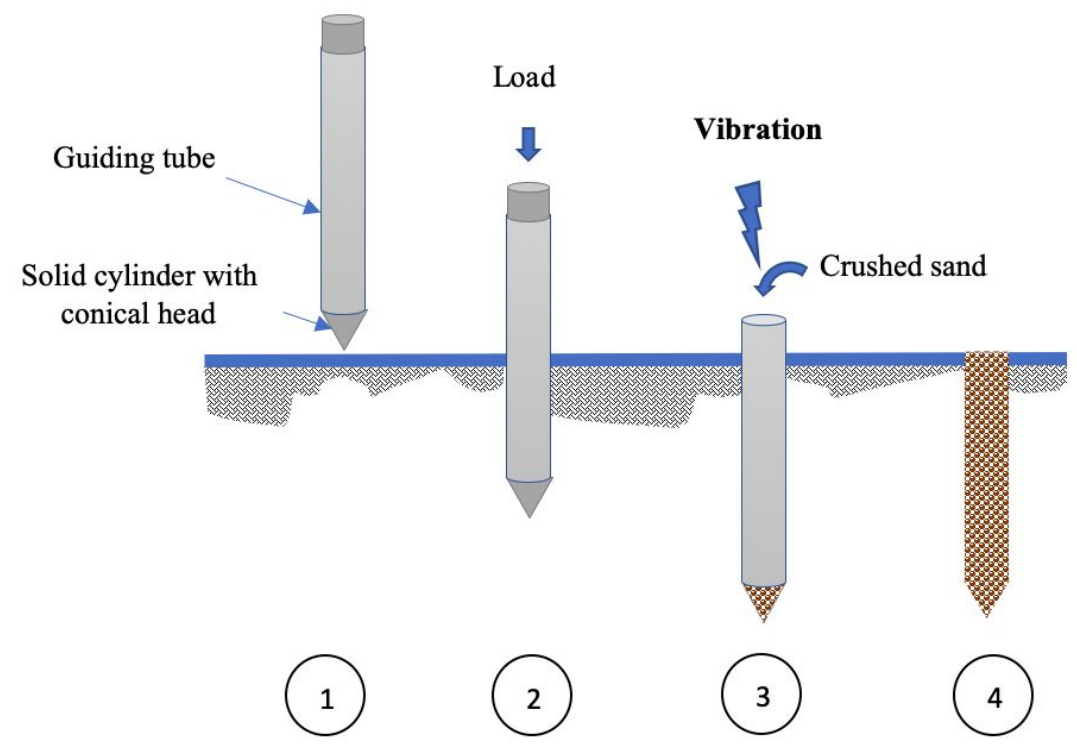


Figure 20. Influence of vibration on reinforced soil by a crushed sand column.

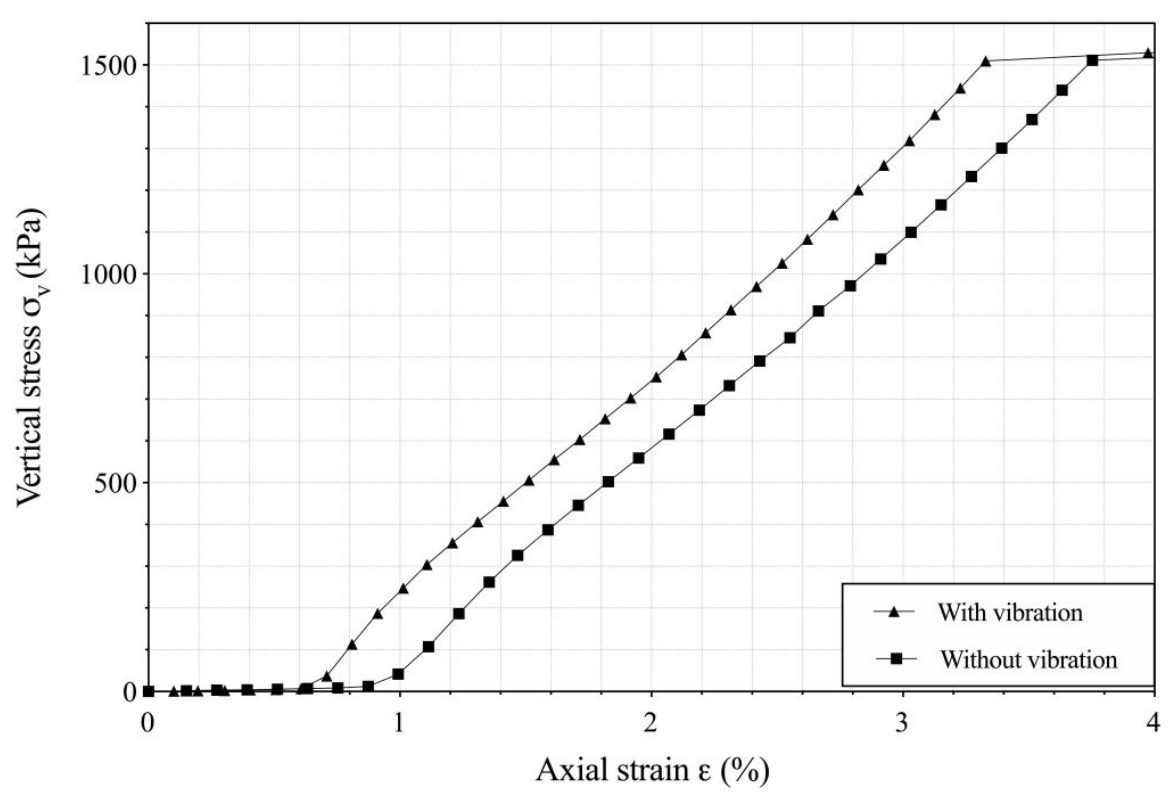


Figure 21. Influence of column spacing for (a) triangular pattern and $(\eta=12 \%)$. (b) rectangular pattern $(\eta=16 \%)$.

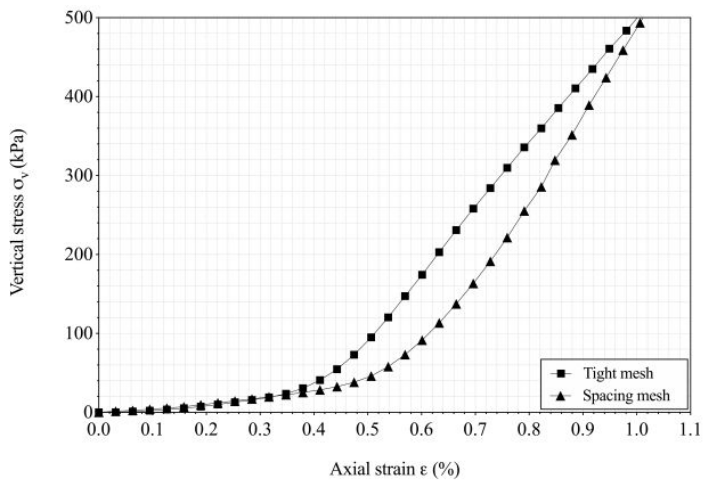

(a)

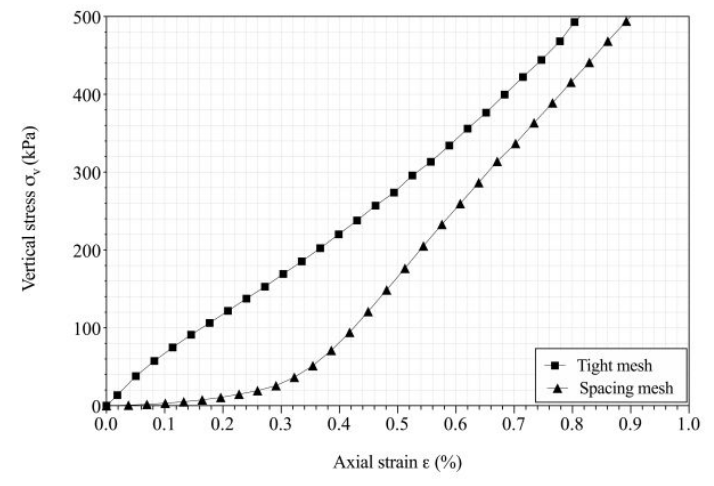

(b) 
Figure 22. Illustration of the areas of influence of each column (a) $\mathrm{s}=30.00 \mathrm{~mm}, \mathrm{~b}$ ) $\mathrm{s}=24.51 \mathrm{~mm}$

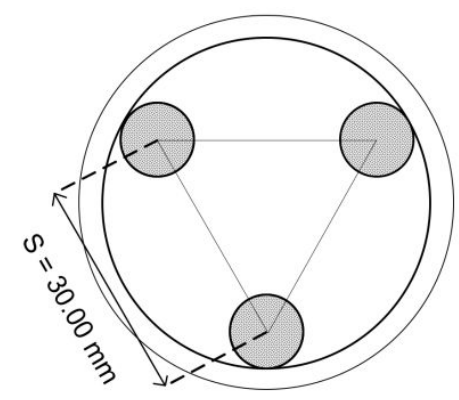

a)

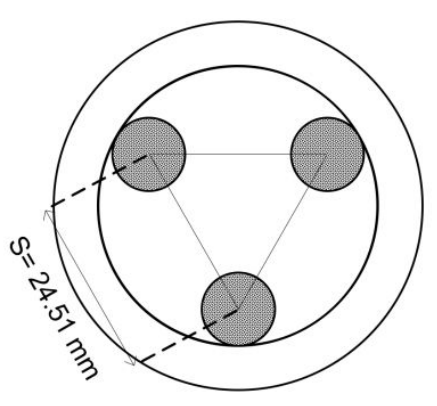

b) 
Figure 23. Illustration of the interaction between the influence zones of stone columns in a triangular mesh as a function of the spacing between the columns ((a) $\mathrm{s}=24.5 \mathrm{~mm}$ and (b) $\mathrm{s}=30.0 \mathrm{~mm}$ ).

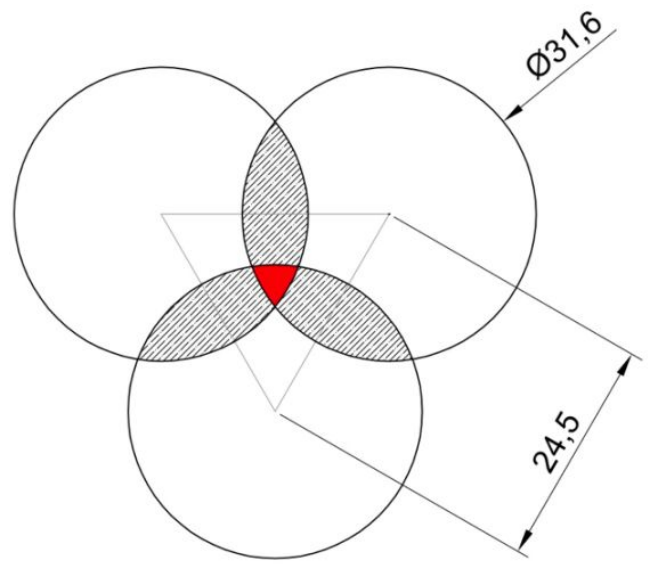

(a)

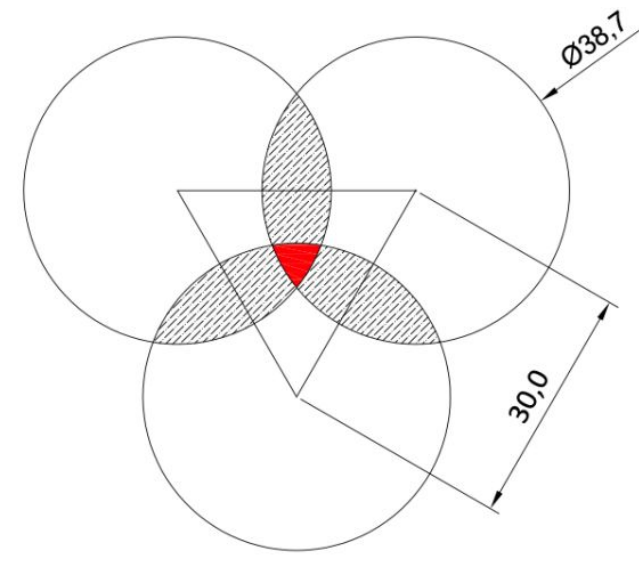

(b) 
Figure 24. Arrangement of a central column (Ellouze et al., 2017).

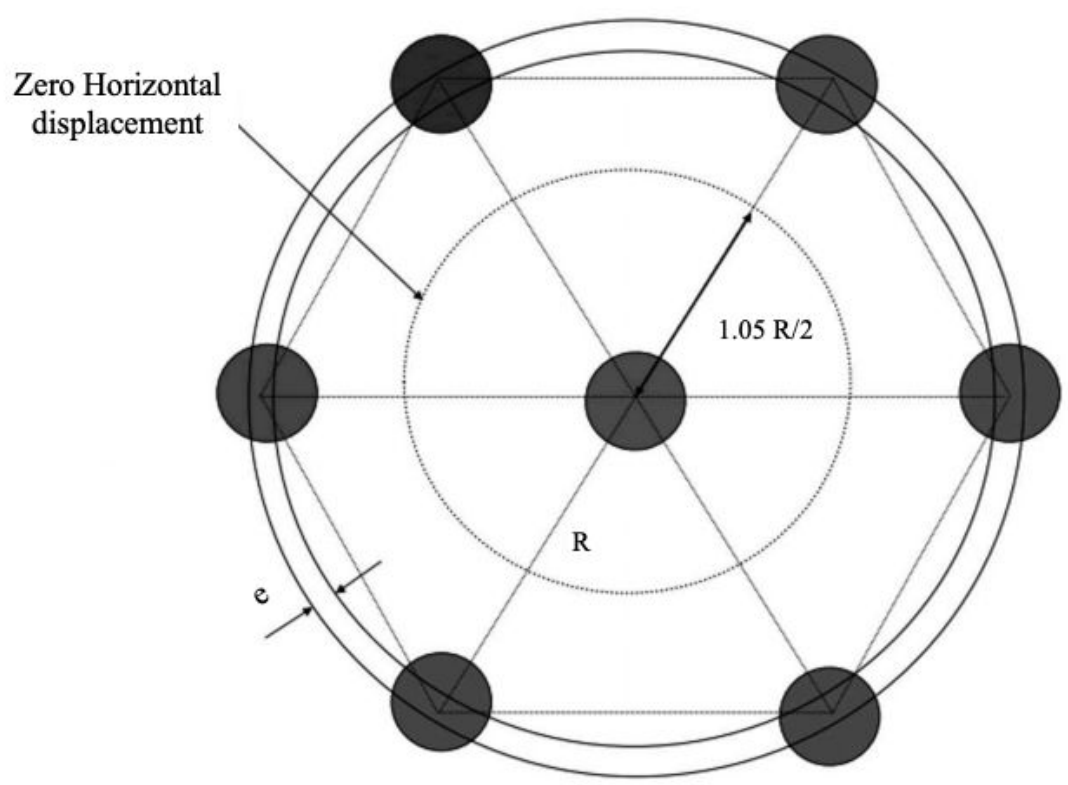


Table 1. Physical and geotechnical properties of tested materials.

\begin{tabular}{|c|c|c|c|}
\hline \multirow[b]{2}{*}{ Parameters } & \multirow{2}{*}{$\begin{array}{c}\text { Soil } \\
\text { Glass beads }\end{array}$} & \multicolumn{2}{|c|}{ column } \\
\hline & & Glass beads & Crushed sand \\
\hline Grain size & $<50 \mu \mathrm{m}$ & $0.7-1.0 \mathrm{~mm}$ & $0.7-1.0 \mathrm{~mm}$ \\
\hline Specific dry mass $\rho_{s}\left(\mathrm{~kg} / \mathrm{m}^{3}\right)$ & $2455 \pm 4$ & $2556 \pm 4$ & $2634 \pm 4$ \\
\hline Coefficient of uniformity $C_{u}(\%)$ & 1.63 & 1.10 & 1.22 \\
\hline Coefficient of curvature $C_{c}(\%)$ & 1.02 & 1.00 & 0.98 \\
\hline Liquid limit $w_{L}(\%)$ & $23.4 \pm 0.3$ & - & - \\
\hline Maximum dry mass $\rho_{d O P N}\left(\mathrm{~kg} / \mathrm{m}^{3}\right)$ & $1920 \pm 10$ & - & - \\
\hline Optimum water content $w_{O P N}(\%)$ & $12.7 \pm 0.2$ & - & - \\
\hline Cohesion $C(\mathrm{kPa})$ & 0 & 0 & 0 \\
\hline Internal friction angle $\phi\left(^{\circ}\right)$ & $23.7 \pm 1.0$ & $25.0 \pm 1.0$ & $35.0 \pm 1.0$ \\
\hline Pre-consolidation stress $\sigma_{p}^{\prime}(\mathrm{kPa})$ & $7 \pm 3$ & - & - \\
\hline Compression index $\lambda(/)$ & 0.05 & - & - \\
\hline Swelling index $\kappa(/)$ & 0.01 & - & - \\
\hline Apparent dry mass $\rho_{d}\left(\mathrm{~kg} / \mathrm{m}^{3}\right)$ & $1350 \pm 10$ & $1570 \pm 10$ & $1430 \pm 10$ \\
\hline Initial water content $w_{0}(\%)$ & $10.0 \pm 0.2$ & 0 & 0 \\
\hline
\end{tabular}


Table 2. Meshing of the stone columns.

\begin{tabular}{|c|c|c|c|c|}
\hline Mesh & $\begin{array}{l}\text { Columns } \\
\text { disposition }\end{array}$ & Illustration & $\begin{array}{l}\text { Substitution factor } \\
\qquad \boldsymbol{\eta}(\%)\end{array}$ & $\begin{array}{c}\text { Interface soil- } \\
\text { column } \\
\left(\mathrm{mm}^{2}\right)\end{array}$ \\
\hline-- & ० & 角 & $4 \%$ & 2481,86 \\
\hline Triangular & & & $12 \%$ & 7445,57 \\
\hline Square & & & $16 \%$ & 9927,43 \\
\hline
\end{tabular}


Table 3. Measured and estimated values of the Young's modulus of the soil reinforced by sand columns.

Measured Young's modulus

$E_{s r}^{e x p}(\mathrm{MPa})$

33.4

37.2
Homogenized Young's modulus

$E_{s r}^{h o m}(\mathrm{MPa})$

58.7 
Table 4. Variation of void ratio during the reinforcement steps as a function of axial deformation.

\begin{tabular}{|c|c|c|c|c|}
\hline Stage & $\begin{array}{c}\text { Number of } \\
\text { columns }\end{array}$ & Before reinforcement & After drilling & Loading \\
\hline \multirow{3}{*}{ Void ratio } & 1 & & $e=0.80$ & $e=0.80-2.6810^{-3} \varepsilon$ \\
\hline & 3 & $e=0.82$ & $e=0.77$ & $e=0.76-2.4610^{-3} \varepsilon$ \\
\hline & 4 & & $e=0.75$ & $e=0.75-2.3510^{-3} \varepsilon$ \\
\hline Illustration & & & & \\
\hline
\end{tabular}


Table 5. Influence diameter as a function of columns' mesh (Dhouib \& Blondeau, 2005).

\begin{tabular}{cccc} 
Mesh & $\begin{array}{c}\text { Spacing between } \\
\text { columns } \\
\mathrm{s} \mathrm{(mm)}\end{array}$ & Formula & $\begin{array}{c}\text { Influence diameter } \\
\mathrm{d}_{\mathrm{e}}(\mathrm{mm})\end{array}$ \\
\hline Triangular & 24.50 & $d_{e}=\sqrt[4]{\frac{16}{\pi^{2}}} s=1.29 \mathrm{~s}$ & 31.61 \\
Square & 24.50 & $d_{e}=\sqrt[4]{\frac{27}{\pi^{2}}} s=1.13 \mathrm{~s}$ & 27.69 \\
& 20 & & 22.60 \\
\hline
\end{tabular}

